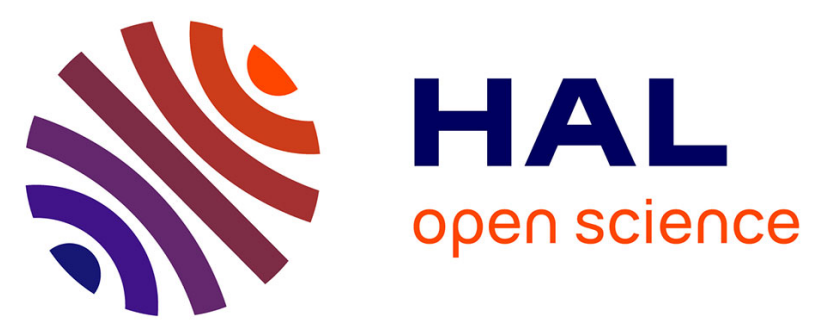

\title{
GEMINI: a Grassland Model Simulating the Role of Plant Traits for Community Dynamics and Ecosystem Functioning. Parameterization and Evaluation
} Jean-Francoise Soussana, Vincent Maire, Nicolas Gross, Bruno Bachelet, Loic Pages, Raphaël Martin, David R.C. Hill, Christian Wirth

\section{To cite this version:}

Jean-Francoise Soussana, Vincent Maire, Nicolas Gross, Bruno Bachelet, Loic Pages, et al.. GEMINI: a Grassland Model Simulating the Role of Plant Traits for Community Dynamics and Ecosystem Functioning. Parameterization and Evaluation. Ecological Modelling, 2012, 231, pp.134-145. 10.1016/j.ecolmodel.2012.02.002 . hal-00707633

\section{HAL Id: hal-00707633 https://hal.science/hal-00707633}

Submitted on 29 May 2020

HAL is a multi-disciplinary open access archive for the deposit and dissemination of scientific research documents, whether they are published or not. The documents may come from teaching and research institutions in France or abroad, or from public or private research centers.
L'archive ouverte pluridisciplinaire HAL, est destinée au dépôt et à la diffusion de documents scientifiques de niveau recherche, publiés ou non, émanant des établissements d'enseignement et de recherche français ou étrangers, des laboratoires publics ou privés. 
Provided for non-commercial research and education use. Not for reproduction, distribution or commercial use.

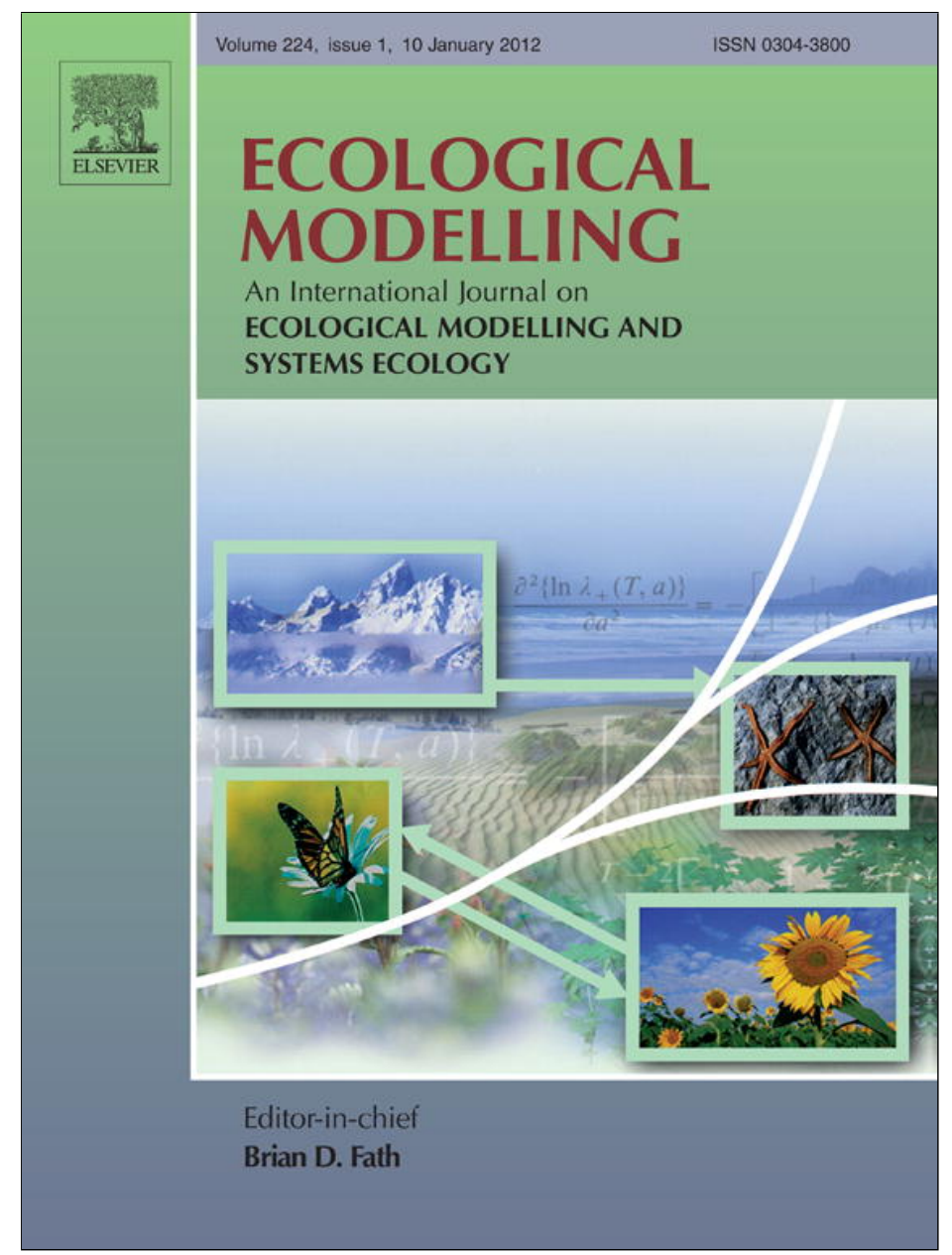

(This is a sample cover image for this issue. The actual cover is not yet available at this time.)

This article appeared in a journal published by Elsevier. The attached copy is furnished to the author for internal non-commercial research and education use, including for instruction at the authors institution and sharing with colleagues.

Other uses, including reproduction and distribution, or selling or licensing copies, or posting to personal, institutional or third party websites are prohibited.

In most cases authors are permitted to post their version of the article (e.g. in Word or Tex form) to their personal website or institutional repository. Authors requiring further information regarding Elsevier's archiving and manuscript policies are encouraged to visit:

http://www.elsevier.com/copyright 


\title{
Gemini: A grassland model simulating the role of plant traits for community dynamics and ecosystem functioning. Parameterization and evaluation
}

\author{
Jean-François Soussana ${ }^{\mathrm{a}, *, 1}$, Vincent Maire ${ }^{\mathrm{a}, 1}$, Nicolas Gross $^{\mathrm{a}, 2}$, Bruno Bachelet $^{\mathrm{a}, 3}$, Loic Pagès ${ }^{\mathrm{b}}$, \\ Raphaël Martin a $^{\mathrm{a}}$, David Hill ${ }^{\mathrm{c}, 4}$, Christian Wirth $^{\mathrm{d}, 5}$ \\ a INRA UR874 UREP, Grassland Ecosystem Research, F-63100 Clermont-Ferrand, France \\ ${ }^{\mathrm{b}}$ Clermont Université, Université Blaise Pascal, LIMOS, BP 10448, F-63000 Clermont-Ferrand, France ${ }^{6}$ \\ ' INRA UR1115 PSH, Plantes et Systèmes de cultures Horticoles, F-84914 Avignon, France \\ ${ }^{\mathrm{d}}$ Max-Planck Institute for Biogeochemistry, D-07745 Jena, Germany
}

\section{A R T I C L E I N F O}

\section{Article history:}

Received 27 October 2010

Received in revised form 31 January 2012

Accepted 6 February 2012

\section{Keywords:}

Partitioning

Growth

Carbon

Nitrogen

Functional balance

Coordination theory

Species diversity

\begin{abstract}
A B S T R A C T
A structure-function-diversity model of grassland ecosystems (Gemini) has been developed. For a potentially unlimited number of clonal plant populations, it explicitly simulates competition for two key resources (light and nitrogen) along vertical canopy and soil profiles. Population turnover, shoot and root morphogenesis, photosynthesis, respiration, transpiration, $\mathrm{N}$ acquisition by uptake, allocation of assimilates between structural compartments, and reserve storage and remobilization, are simulated for each plant population. The object-oriented structure of the modeling framework allows to couple, or not, the simulated plant populations to other sub-models describing climate variables, soil functioning, grazing behavior and grassland management. Partitioning of growth between shoot structures, leaf photosynthetic proteins and roots is based on two assumptions: (i) functional balance between root and shoot activity, (ii) coordination of leaf photosynthesis. The model was parameterized from plant functional trait measurements of 13 native perennial pasture grass species grown in monocultures at high $\mathrm{N}$ availability and low cutting frequency in a field trial. Predicted and measured annual dry-matter yields were highly correlated without bias across species, $\mathrm{N}$ supply and cutting frequency treatments in monocultures and in mixtures of six species. Results show the ability of this mechanistic model to simulate without bias nitrogen and disturbance responses of net primary productivity and of plant community structure.
\end{abstract}

(c) 2012 Elsevier B.V. All rights reserved.

\section{Introduction}

How global changes may influence the dynamics of biodiversity across various levels of biological organization is a key challenge to predict future ecosystem functions and services. Ecosystem response to any environmental change is not only driven by the direct effects of abiotic controls but also indirectly affected by changes in the physiology and morphology of individual plants

\footnotetext{
* Corresponding author. Tel.: +33 473624423.

E-mail address: jfsoussana@clermont.inra.fr (J.-F. Soussana).

1 JFS and VM have contributed equally to this work.

2 Current address: INRA, USC1339 (CEBC-CNRS), F-79360, Beauvoir sur Niort, France; CEBC-CNRS (UPR 1934), F-79360, Beauvoir sur Niort, France.

3 Current address: Clermont Université, Université Blaise Pascal, LIMOS, BP 10448 F-63000 Clermont-Ferrand, France.

4 Current address: CNRS, UMR 6158, LIMOS, F-63173 Aubière, France.

${ }^{5}$ Current address: Universität Leipzig, Institut für Biologie I, 04103 Leipzig, Germany.

${ }^{6}$ Website of the GEMINI project: https://www1.clermont.inra.fr/urep/modeles/ gemini.htm.
}

and by the structure of plant populations and communities (Suding et al., 2008; Klumpp and Soussana, 2009). How individual response scale into ecosystem level is sometimes well-known, e.g. photosynthesis scales from leaf to ecosystem (Field et al., 1992). In contrast, many population (e.g. self-thinning, plasticity) and community processes (e.g. species interactions, species replacement) are not well understood (McGill et al., 2006; Van Wijk, 2007; Gross et al., 2009). An urgent goal for global environmental change research is thus to better understand the consequences of these complex processes at the population and community levels and how they may impact ecosystem functioning (Suding et al., 2008).

Plant functional traits, which are morphological, chemical, physiological and phenological plant characteristics (Lavorel et al., 1997; Violle et al., 2007), have been proposed as a useful tool to upscale individual response into ecosystem level (Lavorel et al., 2007; Suding et al., 2008). Functional traits are linked with individual tolerances to simple abiotic factors (Suding et al., 2003; Louault et al., 2005; Gross et al., 2007a) and biotic interactions (Soussana and Lafarge, 1998; Gross et al., 2007b, 2009; Lavorel et al., 2007). Moreover, functional traits are used to translate individual responses into the community and the ecosystem levels (Schymanski, 2008; 
Suding et al., 2008; Gross et al., 2009). At the ecosystem level, the same traits (community mean-trait, Violle et al., 2007) determine ecosystem functioning through additive (community effect is determined by mass-ratio processes, Klumpp and Soussana, 2009) and non-additive (community effect is determined by complementarity processes, Villeger et al., 2008) effects.

Nevertheless, since almost all empirical studies with plant traits are correlative, the causal linkages between different levels of organizations remain unclear (see review of Lavorel et al., 2007; Savage et al., 2007). A mechanistic approach could help improve our understanding of the role of plant traits for community dynamics and ecosystem functioning (Loreau et al., 2002). Ideally, this approach would assemble within the same framework 'the explicit inclusion of organismal trade-offs, of environmental constraints, and of the basic mechanisms of interspecific interactions' (Tilman, 1990). Such requirements imply developing a novel modeling framework by assembling at least three components: (i) biophysical laws that simulate the energy, carbon and water exchanges between vegetation and atmosphere at ecosystem scale (e.g. Wohlfahrt et al., 2000), (ii) carbon, nitrogen and water cycles in the soil-plant-atmosphere continuum (e.g. Thornley and Johnson, 1990), and (iii) plant population dynamics based on resource competition (e.g. Tilman, 1988).

An individual based approach may offer a valuable perspective to build dynamical structure-function-diversity models for several reasons (Grimm et al., 2006). Across the hierarchy of biological organization levels, selection occurs at the individual level (Marks and Lechowicz, 2006). In addition, individual plants are well defined, measurable and they can be characterized by parameters derived from measured functional traits, that have been recently used for new modeling development in ecology (Lehsten and Kleyer, 2007; Savage et al., 2007; Van Wijk, 2007). Moreover, the individual based approach offers the possibility to simulate plastic adjustments of plant form and function (Yin and Schapendonk, 2004; Hoglind et al., 2001) in response to resource levels mediated by interactions with neighbors.

To date, most dynamic structure-function models based on plant traits concern single trees (Le Roux et al., 2001; Allen et al., 2005; Marks and Lechowicz, 2006). Recently, theoretical models have been developed to demonstrate the role of traits, their diversity, their degree of correlation and their plasticity for ecosystem functioning (Norberg et al., 2001; Savage et al., 2007). However, these models include a few traits only and do not take into account biophysical laws that constrain mass and energy exchange in plant canopies. Dynamic models of pasture grasses (Hoglind et al., 2001; Groot and Lantinga, 2004; Lafarge et al., 2005; Tomlinson et al., 2007) were developed for monocultures. However, these models cannot be used for mixtures and are sometimes restricted to the simulation of a single growing season (Groot and Lantinga, 2004). Finally, non individual-based models simulating mixed grasses (Schippers and Kropff, 2001) and grass-clover growth (Lazzarotto et al., 2009) were previously developed, but they are not based on plant traits framework and they do not include shoot and root morphogenesis.

We have developed from previous works (Soussana et al., 2000a,b) a dynamic structure-function model which simulates average individual plants for each population of a multispecies canopy consisting of perennial $\mathrm{C}_{3}$ grass species. This model called Gemini (Grassland Ecosystem Model with INdividual centred Interactions) is parameterized from a large number of shoot and root traits in each plant population (Table 1). The aims of this structure-function-diversity model are to understand how plant traits interact with abiotic factors to control plant population dynamics, plant community dynamics and ecosystem functioning. In the present paper, we review the key concepts of this model and discuss its parameterization from plant trait measurements. We provide evidence of the model ability to simulate: (i) within and between species variation in above-ground productivity along environmental gradients for grass monocultures, (ii) species dominance in grass mixtures.

\section{Methods}

\subsection{Experimental data}

The experimental site used for model evaluation was established in spring 2002 in an upland area of central France (Theix, $45^{\circ} 43^{\prime} \mathrm{N}, 03^{\circ} 01^{\prime} \mathrm{E}, 870 \mathrm{~m}$ a.s.l.) on a granitic brown soil (Cambisol, FAO). The local climate is semi-continental, with a mean annual temperature of $9^{\circ} \mathrm{C}$ and a mean annual rainfall of $760 \mathrm{~mm} .13$ native perennial $C_{3}$ grass species that co-occur in mesic permanent grasslands were studied in monocultures: Alopecurus pratensis, Anthoxanthum odoratum, Arrhenatherum elatius, Dactylis glomerata, Elytrigia repens, Festuca arundinacea, Festuca rubra, Holcus lanatus, Lolium perenne, Phleum pratense, Poa pratensis, Poa trivialis, Trisetum flavescens. A Lolium perenne cultivar (Clerpin) was added as a control. Henceforth, in the text, species are referred to by their species name. In addition, three mixtures of six species, which were drawn among the 13 species, were also studied. The mixtures were: (i) D. glomerata, F. arundinacea, F. rubra, L. perenne, P. pratensis and C. cristatus; (ii) A. pratensis, A. odoratum, A. elatius, E. repens, $H$. lanatus and T. flavescens; (iii) A. elatius, D. glomerata, E. repens, F. arundinacea, F. rubra and H. lanatus. C. cristatus could not be studied in monoculture as it suffered freezing damage at the time of seedling implantation in monoculture during the winter. This species represented very low abundance $(<2 \%)$ within mixture and was not considered in this study.

The experimental design has 3 complete randomized blocks each crossing two factors: cutting frequency ( 3 and 6 cuts $\mathrm{yr}^{-1}$, $\mathrm{C}_{-}$and $\mathrm{C}+$, respectively) and $\mathrm{N}$ fertilizer supply (120 and $360 \mathrm{kgNha}^{-1} \mathrm{yr}^{-1}, \mathrm{~N}-$ and $\mathrm{N}+$, respectively). Phosphorus and potassium were supplied in spring at non-limiting rates for growth. When soil water content (SWC) was below $10 \%$, all plots were irrigated (see Pontes et al., 2007 for full details). Plant functional traits of monocultures (Table 1) were measured in 2003, 2004 and 2006 in the high $\mathrm{N}$ supply $(\mathrm{N}+)$ and low disturbance $(\mathrm{C}-$ ) treatment (Maire et al., 2009; Pontes et al., 2010). This treatment provided non-limiting conditions for morphogenetic development and above-ground productivity; and was used for model parameterization. Other monoculture treatments $(\mathrm{C}+\mathrm{N}+, \mathrm{C}-\mathrm{N}-, \mathrm{C}+\mathrm{N}-)$ as well as all mixtures were used for an independent evaluation of the model.

\subsection{Model purpose}

The model is described following the ODD (Overview, Design concepts and Details) standard protocol proposed by Grimm et al. (2006) for individual-based and agent-based models. It should be noted that Gemini is an individual-centred model, rather than being individual-based, since it simulates average individuals within each plant (or animal) population. A detailed list of all 132 equations, as well as the 187 variables and the 100 default parameter values and their units is available (at www1.clermont.inra.fr/urep/modeles/gemini.htm) and will be send on request.

The main purpose of Gemini is to understand the dynamics and plasticity of plant species within a community and the role of traits and their plasticity for ecosystem functioning. The model considers climatic (short-wave radiation, temperature and precipitation) and atmospheric $\left(\mathrm{CO}_{2}\right.$ concentration) abiotic drivers. Management conditions concern both disturbance (by cutting and grazing) and fertilization (inorganic and organic $\mathrm{N}$ supply). The model was built 
Table 1

Plant traits used for the calibration of the Gemini model. Abbreviations, units and references are given for each trait ([1] Cornelissen et al., 2003; [2] Kazakou et al., 2007; [3] Pontes et al., 2007; [4] Pontes et al., 2010; [5] Craine et al., 2002). Each trait was used to calibrate one or a few parameters by species. Parameter definitions are provided in Table 2.

\begin{tabular}{|c|c|c|c|c|c|}
\hline Plant functional trait & Abbreviation & Unit & Linked reference & Model parameter & Model mechanism \\
\hline \multicolumn{6}{|l|}{ Leaf morphological trait } \\
\hline Leaf length & $L L$ & $\mathrm{~cm}$ & {$[3,4,5]$} & $L_{\text {leafo }}, F_{\text {sheath }}, b_{\mathrm{AL}}, a_{\mathrm{AL}}, b_{\mathrm{WL}}, a_{\mathrm{WL}}$ & Shoot morphogenesis \\
\hline Sheath length & $S L$ & $\mathrm{~cm}$ & [3] & $F_{\text {sheath }}$ & Shoot morphogenesis \\
\hline Leaf area & $L A$ & $\mathrm{~cm}^{2}$ & [1] & $b_{\mathrm{AL}}, a_{\mathrm{AL}}$ & Shoot morphogenesis \\
\hline Leaf fresh mass & $L F M$ & $\mathrm{mg}$ & [5] & $b_{\mathrm{WL}}, a_{\mathrm{WL}}$ & Shoot morphogenesis \\
\hline Leaf dry mass & $L D M$ & $\mathrm{mg}$ & [5] & $b_{\mathrm{WL}}, a_{\mathrm{WL}}$ & Shoot morphogenesis \\
\hline Leaf dry matter content & LDMC & $\mathrm{mgDMg}^{-1} \mathrm{FM}$ & {$[1,3,5]$} & LDMC & Shoot morphogenesis \\
\hline Specific leaf area & SLA & $\mathrm{m}^{2} \mathrm{~kg}^{-1}$ & {$[1-5]$} & $b_{\mathrm{WL}}$ & Shoot morphogenesis \\
\hline Number of growing leaves & $N G$ & nb tiller ${ }^{-1}$ & {$[4]$} & $n g_{\text {leaf }}$ & Shoot morphogenesis \\
\hline Number of mature leaves & $N M$ & nb tiller ${ }^{-1}$ & {$[4]$} & $n m_{\text {leaf }}$ & Shoot morphogenesis \\
\hline \multicolumn{6}{|l|}{ Root morphological trait } \\
\hline Primary root length & $R L$ & $\mathrm{~cm}$ & [5] & $L L_{\text {plast }}, L_{\text {root1 }}$ & Root morphogenesis \\
\hline Root maximal order & $R O$ & $\mathrm{nb}$ & [5] & $L L_{\text {plast }}, r r_{\text {plast }}$, order $r_{\max }$ & Root morphogenesis \\
\hline Root lifespan & $R L S$ & Degree day & [5] & $T_{\text {root } \mathrm{g} 1}, T_{\text {root } \mathrm{m} 1}$ & Root morphogenesis \\
\hline Primary root diameter & $R D$ & $\mathrm{~mm}$ & {$[1,5]$} & $r r_{\text {plast }}, r r_{\text {root1 }}$ & Root morphogenesis \\
\hline Type of root reserve organ & TRO & Rhizome, stolon... & {$[1]$} & $W_{\text {rrCmax }}, W_{\text {rrNmax }}$ & Root morphogenesis \\
\hline \multicolumn{6}{|l|}{ Plant morphological trait } \\
\hline Vegetative elongated plant height & $V E$ & $\mathrm{~cm}$ & {$[1,5]$} & $C$ & Shoot morphogenesis \\
\hline Tiller density & $T D$ & tillers $\mathrm{m}^{-2}$ & {$[4]$} & intcl, Tsen $_{0}$ & Population dynamic \\
\hline \multicolumn{6}{|l|}{ Plant phenological trait } \\
\hline Earliness of growth & $E G$ & - & {$[4]$} & $b_{\mathrm{LER}}$ & Population dynamic \\
\hline Phyllochron & $\mathrm{PH}$ & Degree day & {$[2,4]$} & $p h_{0}$ & $\begin{array}{l}\text { Shoot morphogenesis, } \\
\text { Population dynamic }\end{array}$ \\
\hline \multicolumn{6}{|l|}{ Leaf and root physiological trait } \\
\hline Leaf $\mathrm{N}$ resorption rate & $R E$ & $\%$ & {$[2]$} & $f_{\mathrm{ns}}, R_{\mathrm{N}}, R_{\mathrm{P}}$ & Physiology \\
\hline Leaf mass loss at senescence & Mass loss & $\%$ & {$[2]$} & $f_{\mathrm{cS}}, R_{\mathrm{C}}$ & Physiology \\
\hline Root $\mathrm{N}$ uptake capacity & $I_{\max }$ & $\mathrm{mgg}^{-1} \mathrm{DM} \mathrm{h}^{-1}$ & {$[1,5]$} & $\mathrm{Su}_{0}$ & Physiology \\
\hline \multicolumn{6}{|c|}{ Leaf and root chemical composition trait } \\
\hline Leaf $\mathrm{N}$ content & $L N C$ & $\mathrm{mg} \mathrm{g}^{-1}$ & {$[1-5]$} & $f_{\mathrm{ns}}$ & Chemical composition \\
\hline Leaf $C$ content & LCC & $\mathrm{mgg}^{-1}$ & {$[5]$} & $f_{\mathrm{cs}}$ & Chemical composition \\
\hline Root $\mathrm{N}$ content & $R N C$ & $\mathrm{mgg}^{-1}$ & [5] & $f_{\mathrm{nr}}$ & Chemical composition \\
\hline Root $C$ content & $R C C$ & $\mathrm{mg} \mathrm{g}^{-1}$ & [5] & $f_{\mathrm{cr}}$ & Chemical composition \\
\hline
\end{tabular}

with a modular architecture, which permits to include or not different biotic agents (plant species, soil microbial decomposers, and herbivores at grazing) as well as different environment and management modules (soil, vegetation, fertilization and cutting).

Gemini can simulate a potentially unlimited number of plant species (or plant populations from the same species) from currently two plant functional types (perennial grasses and legumes). The model focuses on the acquisition and the utilization of two major resources (light and nitrogen) by plants and their consequences for the carbon and nitrogen cycles.

\subsection{State variables and scales}

Gemini consists of vegetation, soil and herbivore sub-models, coupled with environment and management sub-models (Fig. 1). The vegetation sub-model, named Canopt (Soussana et al., 2000a,b) is an individual-centred model of a multi-species stand comprising clonal grasses and/or legumes and forming a multi-layer plant canopy. Each clonal plant population is described as a collection of identical axes (e.g. tillers for grasses). Moreover, all plant species are assumed to be perfectly mixed in the horizontal plane. Plant population demography is calculated from the vegetative multiplication and mortality of axes.

The vegetation sub-model consists of four modules: (i) a biochemical module, which simulates the $\mathrm{C}$ and $\mathrm{N}$ balance and the partitioning of growth among shoot structures $\left(W_{S}\right)$, leaf proteins $\left(W_{\mathrm{P}}\right)$ and roots $\left(W_{\mathrm{R}}\right)$ of a collection of identical axes for each plant population. The corresponding state variables are the number of axes by population $(D)$, the masses of three structural compartments, of two $\mathrm{C}$ and $\mathrm{N}$ substrate compartments and of four $\mathrm{C}$ and $\mathrm{N}$ reserve compartments; (ii) a shoot morphogenesis module, which computes the demography and size of leaves (two state variables, length and mass per leaf); (iii) a root morphogenesis module, which computes the demography and size of roots (two state variables, length and mass, per root); (iv) a competition module which calculates short-wave radiation and inorganic $\mathrm{N}$ partitioning among mixed plant species.

The environment sub-model calculates the microclimate within the canopy and the inorganic $\mathrm{N}$ balance of the soil (or of the substrate when the vegetation model is not coupled to the soil model). The management sub-model schedules events caused by grassland management (cutting dates, grazing periods, $\mathrm{N}$ fertilizer applications).

\subsection{Process overview and scheduling}

The carbon balance is based on Farquhar et al. (1980) equations for leaf photosynthesis which were updated according to Maire (2009). A linear relationship of $V c_{\max }$ (the maximal carboxylation activity of Rubisco) and $J_{\max }$ (the electron transport capacity) with the area based leaf protein concentration (Field, 1983; Nijs et al., $1995)$ is assumed. The vertical profile of leaf proteins is simulated according to Hirose and Werger (1987). Respiration is divided into growth and maintenance components. Leaf respiration varies with leaf protein content.

Nitrogen acquisition is based on soil diffusion processes from soil to roots surface (Barber, 1995). The model separates metabolically active roots and roots which have entered a first stage of senescence (see morphogenesis) and have lost their uptake capacity.

The relative growth rate of the three structural compartments $\left(W_{\mathrm{P}}, W_{\mathrm{S}}, W_{\mathrm{R}}\right)$ is calculated through a bi-substrate $\mathrm{C}-\mathrm{N}$ growth equation using three partitioning variables, one for each compartment (Johnson and Thornley, 1987). The partitioning sub-model specifies a target root/shoot ratio, according to the functional balance hypothesis (Brouwer, 1962; Davidson, 1969; Hilbert and Reynolds, 


\section{GEMINI}
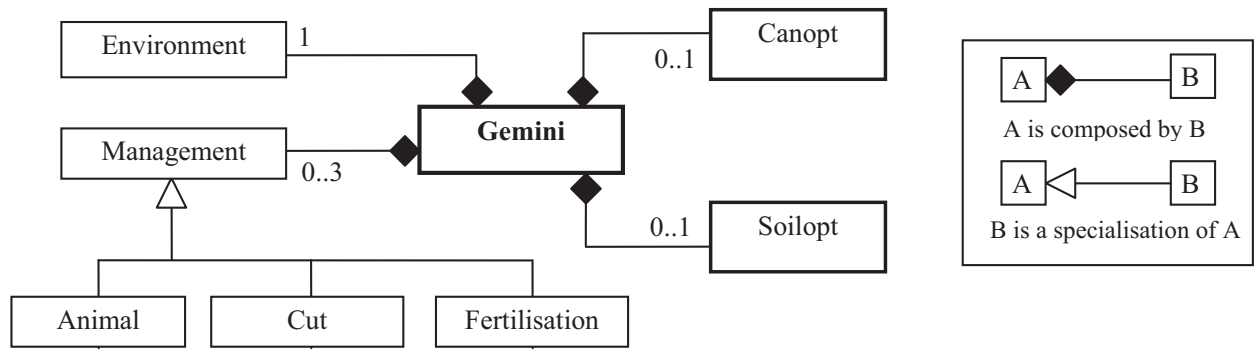

\section{CANOPT}

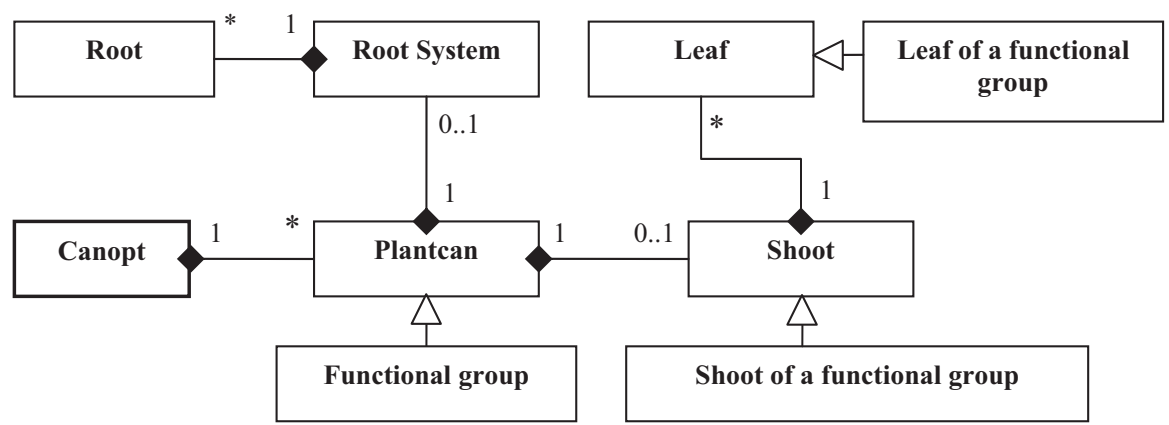

Fig. 1. Unified Model Language (UML) diagram of Gemini model and its modules Canopt (vegetation) and Soilopt (soil, not described here)

1991), and a target protein/structure ratio for leaves, according to the coordination theory of leaf photosynthesis (Chen et al., 1993; Maire, 2009). The $C$ and $N$ substrates are immediately available both for shoot and root developments, although $\mathrm{C}$ and $\mathrm{N}$ reserves are assumed to follow first order kinetics.

The potential leaf extension rate is calculated according to Van Loo (1992). This rate is assumed to increase exponentially with temperature (Lemaire and Agnusdei, 2000). The duration of leaf extension is proportional to the phyllochron (leaf emission per unit thermal time) and to the number of leaves growing simultaneously on the same axis. The potential leaf area and leaf weight are calculated from leaf length through simple allometric relationships. Whenever the supply of assimilates to the shoots does not allow this potential (Poorter, 1994), the leaf extension rate is reduced and the phyllochron is increased. Hence, the model considers a source limitation of shoot growth when assimilates ( $\mathrm{C}$ and $\mathrm{N}$ ) supply to the shoots is less than their potential growth rate. The leaf lifespan is calculated from the maximum number of green leaves per axis (Lemaire and Agnusdei, 2000). Roots decay according to a first order kinetics, based on thermal time. Fixed fractions of the shoot structures, leaf proteins and roots are recycled to the $\mathrm{C}$ and $\mathrm{N}$ substrate compartments during senescence.

Plants are assumed to consist of a collection of identical and anatomically connected axes (e.g. tillers for grasses). A maximum site-filling is assumed (Davies, 1974; Neuteboom and Lantinga, 1989; Van Oijen et al., 2005) to calculate the potential branching (or tillering) rate per unit thermal time. Branching is further constrained by light transmission at ground level (Simon and Lemaire, 1987; Bouman et al., 1996) and by the amounts per plant of $C$ and $\mathrm{N}$ substrates which are available for the growth of new branches (or tillers). According to the degree of physiological integration in the clonal plant, it is considered that only a fraction of $C$ and $\mathrm{N}$ substrates are made available for branching. The baseline mortality rate of axes is calculated from a first order kinetics based on thermal time. This baseline mortality is increased whenever the relative growth rate becomes negative. In this case, mortality rate increases when labile reserves have a low level. During axis senescence, fixed fractions of shoot structures, leaf proteins and roots are recycled to the $\mathrm{C}$ and $\mathrm{N}$ substrate compartments. At each cutting date, it is assumed that all the plant material above cutting height is removed from the patch. The reserve compartments are assumed to be located below the sward defoliation height.

In order to compute a radiative balance, the canopy is divided into fixed height horizontal layers and the light absorbed by leaves from each species in each layer is calculated assuming: (i) a full diffuse radiation, (ii) a perfect mixing of leaves in each horizontal layer. The daily photosynthetically active radiative balance of each population in the mixture is calculated following Sinoquet et al. (2000) using Kubelka-Munk equations for horizontally homogeneous multispecies canopies. Canopy photosynthesis is then calculated for each population by cumulating the leaf photosynthesis of each canopy layer.

Competition for inorganic $\mathrm{N}$ between mixed plant populations is calculated from the total demand for $\mathrm{N}$ uptake (estimated from the uptake capacity and from the cumulated root length of each population). A diffusion approach (Sheehy et al., 1996) is used to calculate the daily amount of $\mathrm{N}$ supplied by the soil to the roots. Whenever $\mathrm{N}$ supply per unit root area is lower than the uptake capacity, the actual uptake rate is calculated by considering that each plant population absorbs the same fraction of its potential demand per unit root area.

\subsection{Software concepts}

The first step of a simulation (Fig. 2) is the construction of the bio-physical model (Part 1 simulation start). The hierarchical structure of the object-oriented code allows for a number of possibilities, including one to $n$ plant species; describing explicitly or not, the root and shoot morphogenesis; including or not one to $n$ soil layers and an animal object. Then, for each simulation day, the main loop (Part 2) goes through three successive steps: (i) update light and $\mathrm{N}$ availability in each horizontal soil and canopy layer; (ii) allocate resources among plant species; (iii) update all objects at the end 


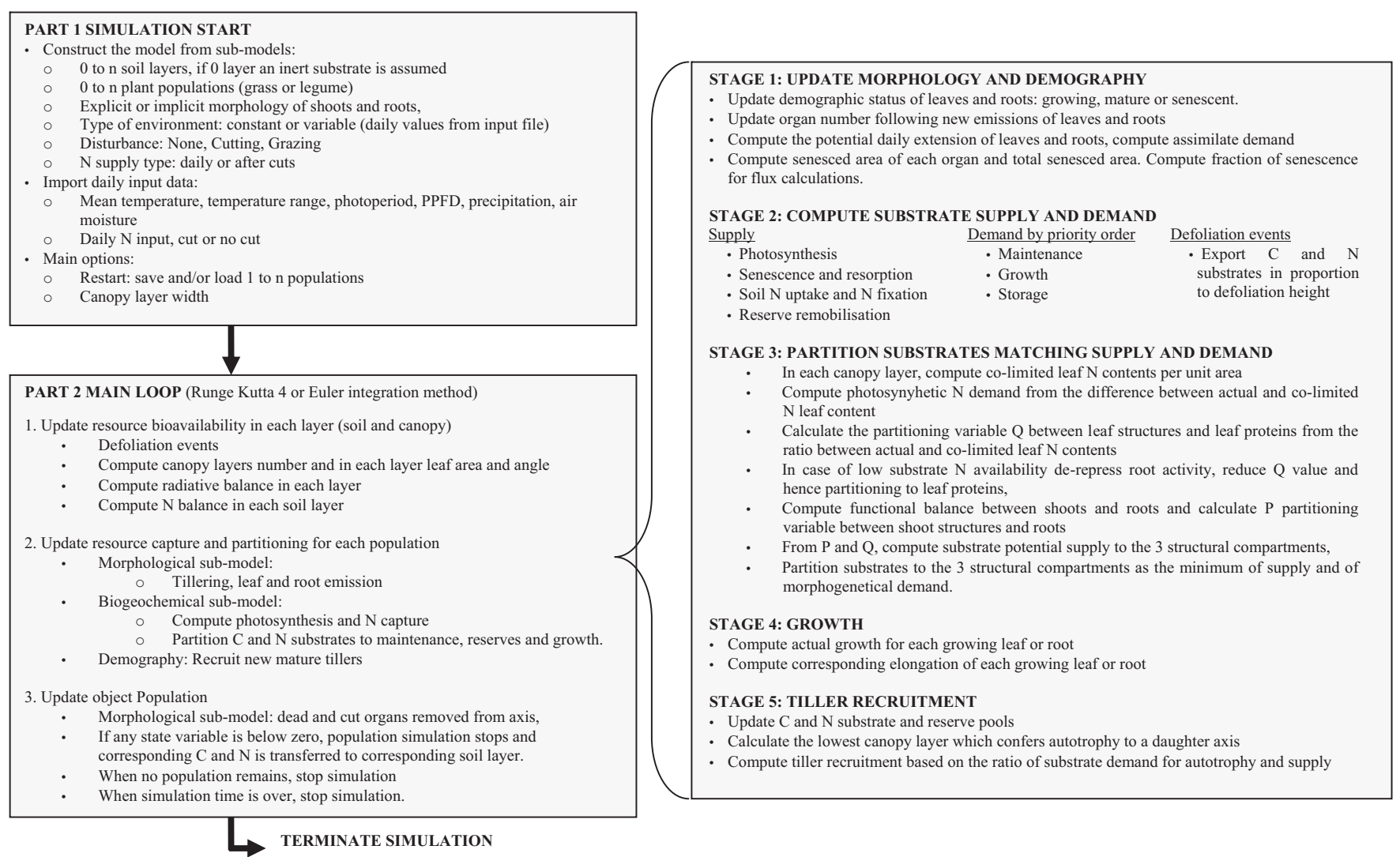

Fig. 2. Algorithmic structure of the vegetation module (Canopt) in the Gemini model.

of simulation day for each species. At the end of the daily loop, the simulation goes one step forward if at least one plant species has survived. The loss of a plant species occurs either when population axis density becomes nil, or when the simulated mean axis has no more substrates.

The model runs on a robust, flexible and portable platform. It allows coupling different numerical sub-models composed by sets of ordinary differential equations (Cellier and Kofman, 2005). This software platform, UNIF (Unified Numerical Integration Framework), is based on a fully object-oriented structure. It has been developed with the $\mathrm{C}^{++}$language and uses the classical relationships of the object-oriented paradigm (mainly inheritance and composition). These objects are referenced in runtime modifiable lists. To check for numerical quality, mass balance ( $\mathrm{C}$ and $\mathrm{N}$ ) is continuously evaluated by independent calculations. Simulations of a plant population were stopped whenever the substrate $C$ concentration increased above an unrealistic value (greater than the structural mass). Moreover, UNIF allows pausing simulation and saving all state variables of user defined objects (e.g. plant populations). This allows for spin-up runs of plant species in monocultures, prior to the construction of a more diverse community. This restart procedure allowed initial plant populations to be close to steadystate.

\subsection{Design concepts}

\subsubsection{Coordination of $C$ and $N$ fluxes}

Coordination of leaf and canopy photosynthesis. The formulation and parameterization used by Maire (2009) for the biochemical of leaf photosynthesis by Farquhar et al. (1980) is used by the model. Assimilation rate is usually limited either by the carboxylase activity of the Rubisco or by the electron flux through the chloroplast photosystems. The maximal rates of these two processes $\left(V c_{\max }\right.$ and $J_{\max }$, respectively) scale linearly with leaf protein content (Wohlfahrt et al., 1998, 1999), which led to the coordination theory (Chen et al., 1993). According to this theory, under given environmental conditions, there is a single leaf $\mathrm{N}$ content which results in a co-limitation of leaf photosynthesis by Rubisco activity and by RuBP regeneration. This area-based leaf photosynthetic protein content $\left(N_{\mathrm{pac}}, \mathrm{gN} \mathrm{m}^{-2}\right)$ maintains a balance between the two processes potentially limiting photosynthesis. Below $N_{\text {pac }}$, the photosynthesis will be limited by the Rubisco activity and therefore by the amount of leaf proteins. Beyond $N_{\mathrm{pac}}$, the marginal gain of photosynthesis per unit of leaf proteins is weak. In the Gemini model, the coordinated leaf $\mathrm{N}$ content is a target concentration for the allocation of assimilates between leaf structure and leaf photosynthetic proteins. This allows calculating a single leaf photosynthetic $\mathrm{N}$ content per unit area $\left(N_{\text {pac }}\right)$, which ensures photosynthesis co-limitation by light and by $\mathrm{CO}_{2}$ capture and use (Soussana et al., 2000a).

$\mathrm{C}$ and $\mathrm{N}$ substrates allocated to leaf proteins are distributed among horizontal canopy layers in proportion to leaf area and to the coordinated leaf protein content per unit leaf area $\left(N_{\text {pac }}\right)$. Along the vertical canopy profile, $N_{\text {pac }}$ declines with transmitted $P P F D$ when all other variables are equal. The coordination theory matches the predicted linear relationship between photosynthetic proteins and transmitted PPFD (Chen et al., 1993) which has often been reported (Lötscher et al., 2003). Air temperature $\left(T_{\mathrm{a}}\right)$, relative humidity $\left(h_{\mathrm{s}}\right)$ and $\mathrm{CO}_{2}$ concentration $\left(C_{\mathrm{a}}\right)$ also vary along the vertical canopy profile. Higher $h_{\mathrm{s}}$ and lower $T_{\mathrm{a}}$ at depth would reduce $N_{\mathrm{pac}}$ for a given $P P F D$, while a lower $C_{\mathrm{a}}$ would increase it. However, variations in $T_{\mathrm{a}}$, $h_{\mathrm{s}}$ and $C_{\mathrm{a}}$ along the vertical canopy profile are currently neglected by the model.

Coordination of $C-N$ fluxes at plant scale. In higher plants, autotrophy is obtained by combining light capture by shoots and nutrients and water capture by roots. For an individual plant, the most 
efficient partitioning of growth would ensure that no resource is in excess, which implies that no single resource becomes limiting (Chapin, 1991). A first version of this multiple resource capture hypothesis is the functional balance hypothesis which assumes that partitioning of growth between shoots and roots tends to balance shoot photosynthesis and root $\mathrm{N}$ acquisition to ensure $\mathrm{C}$ to $\mathrm{N}$ homeostasis. This hypothesis was shown to account for a large number of empirical observations (see the review by Wilson, 1988).

In an original way, Gemini combines the functional balance and photosynthetic coordination theories to determine partitioning rules for potential assimilate supply to the three structural compartments. Following Hilbert and Reynolds (1991), $P$ is the partitioning ratio between shoots structures and roots. $Q$ is the partitioning ratio between shoot structures and leaf proteins. Therefore, the functional balance hypothesis is the main determinant of the balance between shoot structures and roots, while the coordination hypothesis of leaf photosynthesis determines the potential partitioning among leaf proteins and shoot structures. By varying the partitioning ratios between shoots and roots, and between shoot structures and leaf proteins, the model converges towards a co-limitation of plant growth by the captures of light, $\mathrm{CO}_{2}$ and $\mathrm{N}$.

Regulation of root $N$ capture. The model considers that both morphological and physiological plasticity regulate $\mathrm{N}$ capture. First, a hierarchy of root orders with different diameters is considered by the model and differential root growth and branching leads to increased root area per unit mass in case of $\mathrm{N}$ deprivation. Second, the uptake capacity may become down-regulated whenever $\mathrm{N}$ substrate concentration within the plant increases above a fixed threshold (Imsande and Touraine, 1994; Soussana et al., 2002).

\subsubsection{Internal $\mathrm{C}$ and $\mathrm{N}$ recycling}

Storage and remobilization. Pasture grasses accumulate reserve carbohydrates such as fructans and other glucidic polymers mostly within the vacuole. These carbon reserves tend to escape defoliation since they are concentrated within the sheath (Millard, 1988; Jeuffroy et al., 2002).

Gemini considers labile and slow reserve $C$ and $N$ pools. Slow reserve pools are especially important in species developing specialized organs such as rhizomes (e.g. Elytrigia repens) and tap roots (e.g. Festuca paniculata). Both labile and slow reserves are modeled using a buffer formalism that can be tuned to increase remobilization intensity at the expense of the duration of the remobilization period.

Resorption at senescence. Gemini follows the efficiency hypothesis (Franklin and Agren, 2002; Kazakou et al., 2007), by considering distinct efficiencies of resorption for leaf proteins, for carbon and nitrogen both in roots and in shoot structures. Substrate and reserve $\mathrm{C}$ and $\mathrm{N}$ undergo full resorption during senescence. Hence, $\mathrm{C}$ and $\mathrm{N}$ in labile pools (substrates, reserves, and proteins) are assumed to be mostly recycled during senescence, while cell walls from leaf structures are mostly returned to the soil.

\subsubsection{Morphogenesis model}

Plant morphology and architecture. Clonal plants can be seen as colonies of population units, i.e. tillers in grasses (Gillet, 1980). During the vegetative growth of grasses, a single meristem forms all shoots of a population unit, which can therefore best be described as an axis. This axis forms several primary root meristems, usually two per leaf emitted (Matthew et al., 1998). These meristems develop primary roots that may develop secondary meristems leading to the outgrowth of secondary roots. The maximum root branching order is usually less than three in pasture grasses.

This simplified description of plant populations and their morphology is used by the Gemini model which effectively combines three hierarchical levels, the individual root or leaf, the axis and the plant population. Based upon the morphological description at the axis level, the model calculates $2 \mathrm{D}$ architecture by defining the relative positions of the bases and tips of each root and leaf. The relative positions of leaf bases are all located at the soil surface. The azimuth of roots and of leaves is not calculated; therefore the model provides only a 2D description and not a full 3D architecture. Roots are assumed to be linear segments, which length is however greater or equal to the distance between tip and basis, since root tortuosity parameter value can be greater than one. The shape of individual grass leaves is assumed to follow a rectangular hyperbola, which form varies according to the canopy height and tiller density (Soussana et al., 2000b).

This axis-centered 2D architectural description is then scaled up to the population level by assuming that all plant axes are identical, thereby generating a 1D distribution of leaf and of root area in the horizontal canopy and soil layers which are used by the competition sub-model. This simplified approach of plant morphology does not account for stems and for internodes which may position leaf bases in upper canopy layers. Therefore, the morphological sub-model is restricted to vegetative grasses.

Coordination of potential morphogenesis. A general theory of resource distribution through hierarchical branching networks has been applied to the case of vascular plants (West et al., 1999), showing the role of the topology of the branching network for the assimilate demand and for the body size (Enquist and Niklas, 2002). In Gemini, morphogenesis generates a simplified branching network of shoot and root parts through six categories of morphogenetic processes: emission, elongation, vegetative multiplication, branching, senescence and axis death. Each of these processes has a potential temperature dependent rate. Leaf elongation and vegetative multiplication are, in addition, controlled by light-mediated signals (photoperiod and light extinction at ground level, respectively). The number of growing leaves and roots is calculated each day, based on the thermal time between emission and maturity (Lemaire, 1999). For each growing plant part, potential morphogenesis generates each day an additional volume, through an allometric relationship with the length increment generated by elongation. Hence, the total volume increment generated by shoots and roots growth can be calculated on a daily basis per plant axis.

Some morphogenetic processes are coordinated. The thermal time between two successive emission events of leaves or roots (i.e. the phyllochron for leaves) is used as a biological clock controlling the ontogeny of the plant. First, the duration of leaf elongation varies with phyllochron (Lemaire, 1999), since the number of growing leaves per axis is assumed to be constant (between 1 and 2 for grasses, Gillet, 1980). Second, leaf senescence starts after a thermal time which is a multiple of the phyllochron since the number of mature leaves per axis is assumed to be constant. Third, vegetative multiplication is also constrained by phyllochron, since the potential site-filling rule (Neuteboom and Lantinga, 1989) states that the number of axillary buds varies with leaf number and, hence, with phyllochron.

While roots and leaves share common properties (in terms of emission and elongation), roots also have specific properties. Root hierarchy constrains the emission rate, the diameter, length and longevity of roots. Roots of higher order are emitted more frequently, are thinner, shorter and short-lived compared to roots of lower branching order (Pagès et al., 2004).

Root branching only occurs for roots with an order lower than the maximum (e.g. when the maximum branching order is 3, only primary and secondary roots can branch). The model implicitly assumes that a pair of primary roots is emitted for each phyllochron. However, the primary roots turnover is not explicitly simulated on the average axis, since the primary roots death corresponds to axis death, which is simulated through the axis mortality process. Rather, axis death is calculated at the population level, through a 
baseline death rate which is increased whenever relative growth rate becomes negative and when reserves are low.

Leaf and root (of order greater than one) senescence affects the area of these plant parts. With leaves, senescence starts from the leaf tip and progresses towards the leaf basis. Dead leaves are assumed to be detached from the plant axis. Root senescence is also a gradual process, with three successive stages: (i) transition from metabolically active roots to roots which have lost active metabolism but can still transport water, (ii) transition from 'passive' roots to dead but still attached roots, (iii) dead and detached roots. Leaf and root senescence tend to balance emission, thereby leading to a steady-state architecture which converges towards a constant number of growing, mature and senescing leaves and of active, passive and dead primary and higher order roots. Therefore, potential rates of the morphogenetic processes constrain the morphology and architecture of the plant populations, leading to coordination between leaf and root numbers.

\subsection{Model parameterization}

Out of a total of 100 parameters, 65 have been considered as constant across the 13 perennial grass species investigated with a value taken from the literature. The remaining parameters (Table 2) were calculated from plant trait values measured in the field experiment comparing 13 grass species grown in monocultures in the $\mathrm{C}-\mathrm{N}+$ management treatment. In this treatment, neither nutrients nor water resources were limiting above-ground grass growth (Pontes et al., 2007; Maire et al., 2009).

Shoot morphology parameters were derived from single trait measurements (for $L_{\text {leafo, }}$, maximal leaf length, $F_{\text {sheath }}$, fraction of sheath in total leaf length; $n g_{\text {leaf }}, n m_{\text {leaf }}$, growing and mature leaf number per tiller, $p h_{0}$, phyllochron and $L D M C$, leaf lamina dry-matter per unit fresh-matter), or from combined trait measurements (for leaf allometry parameters $a_{\mathrm{AL}}, b_{\mathrm{AL}}, a_{\mathrm{WL}}, b_{\mathrm{WL}}$ were fitted from relationships between lamina area or volume and leaf length). The last two remaining shoot parameters ( $C$, which controls leaf lamina angle for a given canopy height and density, and $b_{\mathrm{LER}}$, power coefficient of temperature response of leaf elongation) were estimated from measurements of leaf angles and from observations of earliness of vegetative spring growth, respectively.

Root morphology parameters were derived from measurements on root ingrowth cores filled with vermiculite and supplied with slow release fertilizers (for full details see Maire et al., 2009). In the same way, parameter values were derived from single trait measurement ( $r r_{\text {root1 }}$, radius of primary roots, $R D M C$, root drymatter content, Order $_{\max }$, maximum root branching order), or from combined traits measurements (Orl, branching order dependency, which were obtained from radius measurements of root orders). $L_{\text {rootmax } 1}$, the potential length of primary roots was estimated from Kutschera (1960) root atlas and from the correlation between maximal plant height and rooting depth (Craine et al., 2002).

Two parameters ( $L L_{\text {plast }}$, the branching order dependency of potential root length and $T r$, the thermal time interval between two successive root emission events) were optimized by maximizing axis biomass $\left(W_{\mathrm{G}}\right)$. This first optimization was done on $\mathrm{C}-\mathrm{N}+$ management treatment using constant axis density for each species. The two population demography parameters (intcl, the clonal integration and $T \mathrm{Tse}_{0}$, the lifespan of an axis) were then optimized by fitting simulated to measured tiller density $(D)$ per unit ground area. This second optimization was done after the root parameters optimization.

Root chemical composition parameters were derived from measured $\mathrm{C}$ and $\mathrm{N}$ contents in below-ground plant parts. $\mathrm{C}$ fraction in shoot structures was derived from measurements in mature green leaves. The $\mathrm{N}$ fraction of shoot structures was estimated from the measured $\mathrm{N}$ contents of senescent leaves (Maire et al., 2009).
Finally, species specific physiological parameters measurements were derived from measurements of (i) $\mathrm{N}\left(R_{\mathrm{P}}\right)$ and dry-matter $\left(R_{\mathrm{C}}, R_{\mathrm{N}}\right)$ resorption during leaf senescence (Maire et al., 2009), (ii) root $\mathrm{N}$ uptake potentials $\left(\mathrm{Su}_{0}\right)$ in root ingrowth cores (Maire et al., 2009). The potential size of the slow $C$ reserve pool $\left(W_{\text {rrCmax }}\right)$ was estimated for each species as the minimum size stabilizing the $C$ substrate pool during winter. The potential size of the slow $\mathrm{N}$ reserve pool was estimated at one tenth of that of the slow $C$ reserve pool.

\subsection{Model evaluation}

The model was then evaluated by comparing simulated to observed above-ground DM productivity in 2004, two years after the start of experiment, with monocultures of the 13 grass species at low cutting frequency $(\mathrm{C}-$ ) and at low $\mathrm{N}$ under high cutting frequency $(\mathrm{C}+, \mathrm{N}-)$, that is for experimental treatments which were not used for model parameterization. Finally, the model was evaluated by comparing simulated and observed species relative abundance in three mixtures of six out of the 13 species (see Pontes et al., 2012).

In monocultures, the restart procedure was used to initialize all simulations. In mixtures, an initial total density of 1000 axes $\mathrm{m}^{-2}$ (equally distributed among the six species) was assumed. For comparison with field data, simulations were run with daily climatic data recorded at the experimental site in 2003 and 2004 (temperature, $P P F D$, precipitation and air humidity). The same timing (day of year) was applied for the fertilization and cutting events in the model and in the experimental treatments, as well as the same amounts of fertilizer N supply. Since there was no soil assumed, a daily net soil mineralization was assumed at $0.11 \mathrm{gN} \mathrm{m}^{-2} \mathrm{~d}^{-1}$. The dynamics of $\mathrm{N}$ fertilizer release in the soil were simulated, assuming a pulse and decline over one month.

The model was evaluated by using four complementary indices (Willmott, 1982; Stöckle et al., 2004) which compare simulated and measured above-ground DM yields of species monocultures and species abundance in mixtures. The index of agreement $(d)$, which is ranged between 0 and 1 ( 1 indicating perfect agreement), gives the standard error variability (Eq. (I)). A d value above 0.9 was considered as acceptable error. The relative root mean square error (RE), which is bounded by 0 indicating perfect agreement between simulated and measured values, gives the general standard deviation from the measured mean by placing, however, relatively more weight on high quadratic error values (Eq. (II)). A RE value below 0.2 was considered as acceptable error. Since RE does not specify the error source, a ratio between systematic $\left(R E_{S}\right)$ and unsystematic $\left(\mathrm{RE}_{\mathrm{U}}\right)$ errors was also calculated according to (Eq. (III)).

$$
\begin{aligned}
& d=1-\frac{\sum_{i=1}^{n}\left(E_{i}-M_{i}\right)^{2}}{\sum_{i=1}^{n}\left(\left|E_{i}-\bar{M}\right|+\left|M_{i}-\bar{M}\right|\right)^{2}} \\
& \mathrm{RE}=\left[\frac{\sum_{i=1}^{n}\left(E_{i}-M_{i}\right)^{2}}{n}\right]^{0.5} \cdot \frac{1}{\bar{M}} \\
& \frac{R E_{S}}{R E_{U}}=\frac{\sum_{i=1}^{n}\left(\hat{E}_{i}-M_{i}\right)^{2}}{\sum_{i=1}^{n}\left(E_{i}-\hat{E}_{i}\right)^{2}} \text { with } \hat{E}_{i}=b \cdot M_{i}+a
\end{aligned}
$$

where $E_{i}$ and $M_{i}$ are the simulated and measured values of one variable of species $i, \bar{M}_{i}$ is the average of $M_{i}$ and $\hat{E}_{i}$ is an estimate of $E_{i}$, which is derived from the linear regression between $E_{i}$ and $M_{i}$.

The slope of reduced major axis regressions (RMA slope) between estimated and measured values is also an index of model under-or-over-prediction trends. Finally, to test the model ability to simulate cross-species differences, simulated and measured Spearman's ranks of species were compared. Rank tests were performed 
Table 2

Calibration of the vegetation module (Canopt) of Gemini. (A) Species specific parameter values for the 13 native grasses and for the control Lolium perenne (Clerpin) cultivar. (B) Initial value of the state variables.

\begin{tabular}{|c|c|c|c|c|c|c|c|c|c|c|c|c|c|c|}
\hline Symbol & Ap & Ao & $\mathrm{Ae}$ & $\mathrm{Dg}$ & Er & Fa & $\mathrm{Fr}$ & $\mathrm{Hl}$ & Lp & $\mathrm{Cl}$ & Php & $\mathrm{Pp}$ & $\mathrm{Pt}$ & Tf \\
\hline \multirow{2}{*}{\multicolumn{15}{|c|}{$\begin{array}{l}\text { (A) Full model } \\
\text { Shoot morphology at axis scale }\end{array}$}} \\
\hline & & & & & & & & & & & & & & \\
\hline$a_{\mathrm{AL}}\left(\mathrm{cm}^{2} \mathrm{~cm}^{-1}\right)$ & 0.138 & 0.216 & 0.074 & 0.160 & 0.054 & 0.314 & 0.143 & 0.398 & 0.050 & 0.042 & 0.055 & 0.459 & 0.043 & 0.022 \\
\hline$a_{\mathrm{WL}}\left(\mathrm{cm}^{2} \mathrm{~cm}^{-1}\right)$ & 0.00204 & 0.00340 & 0.00105 & 0.00278 & 0.00075 & 0.00610 & 0.00359 & 0.00572 & 0.00095 & 0.000828 & 0.00069 & 0.00718 & 0.00063 & 0.00030 \\
\hline$b_{\mathrm{AL}}$ (dimensionless) & 1.158 & 1.110 & 1.358 & 1.201 & 1.472 & 1.081 & 0.913 & 0.927 & 1.359 & 1.387 & 1.419 & 0.747 & 1.311 & 1.736 \\
\hline$b_{\text {LER }}$ (dimensionless) & 2.08 & 1.65 & 1.9 & 1.8 & 1.9 & 1.29 & 2.1 & 1.15 & 1.42 & 2.00 & 1.2 & 1.35 & 2.23 & 2.12 \\
\hline$b_{\mathrm{WL}}$ (dimensionless) & 1.158 & 1.110 & 1.358 & 1.201 & 1.472 & 1.081 & 0.913 & 0.927 & 1.359 & 1.387 & 1.419 & 0.747 & 1.311 & 1.736 \\
\hline$C$ (dimensionless) & 0.12 & 0.16 & 0.12 & 0.12 & 0.12 & & 0.08 & 0.12 & 0.12 & & 0.10 & 0.10 & 0.18 & 0.12 \\
\hline$F_{\text {sheath }}(0-1)$ & 0.313 & 0.270 & 0.309 & 0.261 & 0.285 & 0.204 & 0.225 & 0.353 & 0.253 & 0.300 & 0.337 & 0.232 & 0.360 & 0.320 \\
\hline$L_{\text {leafo }}(\mathrm{cm})$ & 57.0 & 31.6 & 43.1 & 52.0 & 48.9 & 54.0 & 29.3 & 49.4 & 40.9 & 41.6 & 33.8 & 35.3 & 21.7 & 32.4 \\
\hline LDMC $\left(\mathrm{gDM} \mathrm{g}^{-1} \mathrm{FM}\right)$ & 0.215 & 0.192 & 0.182 & 0.193 & 0.205 & 0.215 & 0.250 & 0.174 & 0.185 & 0.166 & 0.206 & 0.232 & 0.236 & 0.211 \\
\hline $\mathrm{ng}_{\text {leaf }}\left(\right.$ leaves axis ${ }^{-1}$ ) & 1.17 & 1.12 & 1.18 & 1.79 & 1.21 & 1.01 & 1.03 & 1.14 & 1.16 & 1.22 & 1.36 & 1.11 & 1.18 & 1.23 \\
\hline $\mathrm{nm}_{\text {leaf }}$ (leaves axis ${ }^{-1}$ ) & 2.71 & 2.41 & 2.44 & 2.53 & 2.53 & 2.00 & 2.70 & 2.38 & 2.42 & 2.28 & 2.73 & 2.23 & 3.16 & 2.53 \\
\hline $\mathrm{ph}_{0}\left({ }^{\circ} \mathrm{Cd}\right)$ & 163.5 & 200.0 & 162.1 & 142.0 & 157.0 & 220.0 & 239.3 & 130 & 154.4 & 212.0 & 120.0 & 220.0 & 115.0 & 200.0 \\
\hline \multicolumn{15}{|c|}{ Root morphology at axis scale } \\
\hline $\mathrm{LL}_{\text {plast }}$ (dimensionless) & 1.114 & 0.589 & 0.691 & 0.764 & 0.866 & 1.500 & 0.752 & 0.607 & 0.837 & 0.691 & 0.626 & 0.599 & 0.541 & 0.462 \\
\hline $\mathrm{L}_{\text {rootmax } 1}(\mathrm{~cm})$ & 52 & 39 & 42 & 50 & 49 & 52 & 32 & 50 & 39 & 48 & 33 & 45 & 32 & 38 \\
\hline $\mathrm{Nm}_{\text {Roots } 1}\left(\right.$ roots axis $\left.{ }^{-1}\right)$ & 6 & 8 & 6 & 8 & 6 & 8 & 6 & 6 & 6 & 6 & 8 & 6 & 8 & 6 \\
\hline OrL (dimensionless) & 3.50 & 2.20 & 3.30 & 3.05 & 3. 80 & 1.4 & 2.90 & 2.10 & 4.50 & 3.00 & 2.30 & 2.20 & 4.27 & 2.70 \\
\hline $\operatorname{RDMC}\left(\mathrm{gDM} \mathrm{g}^{-1} \mathrm{FM}\right)$ & 0.130 & 0.110 & 0.170 & 0.144 & 0.147 & 0.139 & 0.121 & 0.136 & 0.118 & 0.110 & 0.170 & 0.150 & 0.120 & 0.130 \\
\hline $\mathrm{rr}_{\text {root1 } 1}(\mathrm{~cm})$ & 0.0285 & 0.0161 & 0.0215 & 0.0221 & 0.0227 & 0.0310 & 0.0210 & 0.0160 & 0.0238 & 0.0170 & 0.0157 & 0.0171 & 0.0135 & 0.0147 \\
\hline $\mathrm{rr}_{\text {plast }}$ (dimensionless) & 1.114 & 0.589 & 0.691 & 0.764 & 0.866 & 1.500 & 0.752 & 0.607 & 0.837 & 0.691 & 0.626 & 0.599 & 0.541 & 0.462 \\
\hline$T_{\text {rootg1 } 1}\left({ }^{\circ} \mathrm{Cd}\right)$ & 300 & 500 & 300 & 300 & 300 & 300 & 300 & 300 & 300 & 300 & 300 & 300 & 300 & 300 \\
\hline$T_{\text {rootm1 } 1}\left({ }^{\circ} \mathrm{Cd}\right)$ & 500 & 200 & 500 & 500 & 500 & 500 & 500 & 500 & 600 & 500 & 500 & 500 & 500 & 500 \\
\hline$T_{\mathrm{r}}\left({ }^{\circ} \mathrm{Cd}\right)$ & 80 & 28 & 40 & 45 & 49 & 52 & 65 & 45 & 150 & 50 & 40 & 70 & 20 & 32 \\
\hline \multicolumn{15}{|c|}{ Morphology at population scale } \\
\hline $\operatorname{Intcl}(0-1)$ & 0.185 & 0.22 & 0.22 & 0.255 & 0.205 & 0.245 & 0.258 & 0.25 & 0.22 & 0.18 & 0.21 & 0.23 & 0.15 & 0.24 \\
\hline $\operatorname{Tsen}_{0}\left({ }^{\circ} \mathrm{C}^{-1} \mathrm{~d}^{-1}\right)$ & 0.0051 & 0.0051 & 0.007 & 0.0074 & 0.0052 & 0.0043 & 0.00425 & 0.00525 & 0.0073 & 0.0043 & 0.007 & 0.0035 & 0.007 & 0.0055 \\
\hline \multicolumn{15}{|l|}{ Chemical composition } \\
\hline$f_{\mathrm{CS}}\left(\mathrm{gCg}^{-1} \mathrm{DM}\right)$ & 0.425 & 0.433 & 0.429 & 0.429 & 0.419 & 0.432 & 0.441 & 0.424 & 0.439 & 0.435 & 0.432 & 0.434 & 0.419 & 0.432 \\
\hline$f_{\mathrm{Cr}}\left(\mathrm{gCg}^{-1} \mathrm{DM}\right)$ & 0.414 & 0.433 & 0.428 & 0.435 & 0.428 & 0.422 & 0.427 & 0.425 & 0.428 & 0.428 & 0.437 & 0.425 & 0.417 & 0.425 \\
\hline$f_{\mathrm{nS}}\left(\mathrm{gNg}^{-1} \mathrm{DM}\right)$ & 0.0173 & 0.0173 & 0.0238 & 0.0094 & 0.0106 & 0.0087 & 0.0137 & 0.0092 & 0.0182 & 0.0099 & 0.0123 & 0.0137 & 0.0224 & 0.0193 \\
\hline \multicolumn{15}{|l|}{ Physiology (@ $T_{\text {ref }}=20^{\circ} \mathrm{C}$ ) } \\
\hline$R_{C}(0-1)$ & 0.362 & 0.522 & 0.279 & 0.408 & 0.372 & 0.258 & 0.302 & 0.498 & 0.251 & 0.385 & 0.469 & 0.269 & 0.368 & 0.319 \\
\hline$R_{\mathrm{N}}(0-$ & 0.362 & 0.522 & 0.279 & 0.408 & 0.372 & 0.25 & 0.302 & 0.498 & 0.251 & 0.385 & 0.469 & 0.269 & 0.368 & 0.319 \\
\hline$R_{\mathrm{P}}(0-1)$ & 0.421 & 0.592 & 0.253 & 0.623 & 0.585 & 0.546 & 0.490 & 0.627 & 0.330 & 0.635 & 0.590 & 0.453 & 0.377 & 0.398 \\
\hline $\mathrm{Su}_{0}\left(\mathrm{gN} \mathrm{m}^{-2} \operatorname{rootd}^{-1}\right)$ & 0.1318 & 0.0618 & 0.2376 & 0.1282 & 0.1810 & 0.0750 & 0.0928 & 0.0710 & 0.0564 & 0.0960 & 0.0485 & 0.1404 & 0.0933 & 0.0493 \\
\hline $\mathrm{W}_{\text {rrCmax }}\left(\mathrm{gCaxis}^{-1}\right)$ & 0.01 & 0.01 & 0.01 & 0.01 & 0.02 & 0.04 & 0.01 & 0.01 & 0.01 & 0 & 0.01 & 0.01 & 0 & 0.01 \\
\hline $\mathrm{W}_{\mathrm{rrNmax}}\left(\mathrm{gNaxis}^{-1}\right)$ & 0.001 & 0.001 & 0.001 & 0.001 & 0.002 & 0.004 & 0.001 & 0.001 & 0.001 & 0 & 0.001 & 0.001 & 0 & 0.001 \\
\hline
\end{tabular}

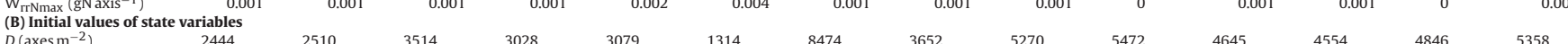

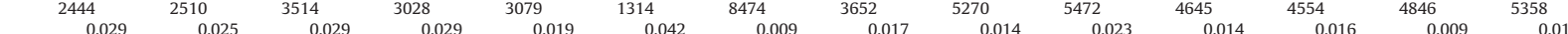

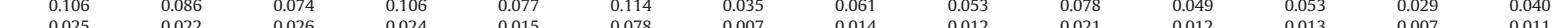

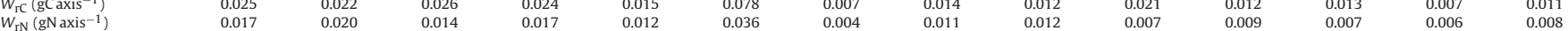

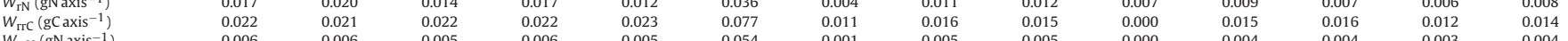

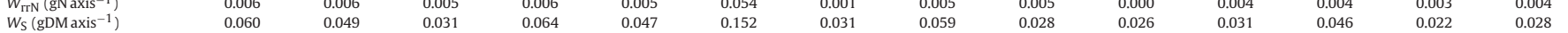

Parameter abbreviations: $a_{\mathrm{AL}}, b_{\mathrm{AL}}, a_{\mathrm{WL}}, b_{\mathrm{WL}}$ leaf allometry parameters fitted from relationships between lamina area or volume and leaf length; $b_{\mathrm{LER}}$, power coefficient of temperature response of leaf elongation; $C$, parameter

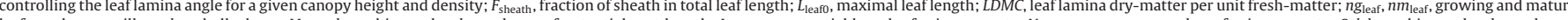

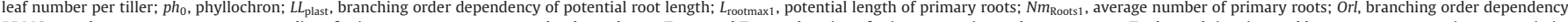

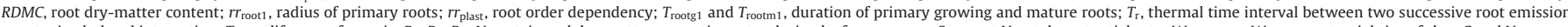
events; intcl, clonal integration; $T s e n_{0}$, lifespan of an axis; $R_{\mathrm{P}}, R_{\mathrm{C}}, R_{\mathrm{N}}, \mathrm{N}$ protein and dry-matter resorption rates during leaf senescence; $\mathrm{Su}_{0}$, root $\mathrm{N}$ uptake potential rate; $W_{\text {rrCmax and }} W_{\text {rrNmax }}$, potential size of slow $\mathrm{C}$ and $\mathrm{N}$ reserve pools; $W_{\mathrm{S}}, W_{\mathrm{P}}$ and $W_{\mathrm{R}}$, structural compartments of shoot structures; leaf proteins and roots, respectively; $D$, number of axes per population and per square meter; $W_{\mathrm{C}}$ and $W_{\mathrm{N}}$, mass of $\mathrm{C}$ and $\mathrm{N}$ substrate compartments; $W_{\mathrm{rC}}$ and

Species abbreviations are: Alopecurus pratensis (Ap), Anthoxanthum odoratum (Ao), Arrhenatherum elatius (Ae), Dactylis glomerata (Dg), Elytrigia repens (Er), Festuca arundinacea (Fa), Festuca rubra (Fr), Holcus lanatus (HI), Lolium perenne (Lp), Lolium perenne cultivar (Cl), Phleum pratense (Php), Poa pratensis (Pp), Poa trivialis (Pt), Trisetum flavescens (Tf). 
Table 3

Statistical indices used for Gemini model evaluation comparing simulated and measured values of (A) above-ground dry matter yield of 13 monocultures and (B) species abundance in three different mixtures of six species, each being cultivated in four management treatments $(\mathrm{C}-\mathrm{N}+, \mathrm{C}+\mathrm{N}+, \mathrm{C}-\mathrm{N}-$ and $\mathrm{C}+\mathrm{N}-)$. Four complementary indices were used (see Methods): (i) index of agreement $(d)$ where 1 indicates perfect agreement; (ii) relative root mean square error (RE), where 0 indicates perfect agreement; (iii) ratio between systematic $\left(R E_{S}\right)$ and unsystematic $\left(R E_{U}\right)$ errors (iv) slope of reduced major axis regressions (RMA slope) and significance of its difference to one $(p<0.05)$. Additionally, simulated and observed species ranks were compared (Spearman's rank test) at $p<0.05$ and $p<0.01$.

\begin{tabular}{lllllll}
\hline \multicolumn{1}{l}{$d$} & $\mathrm{RE}$ & $\mathrm{RE}_{\mathrm{S}} / \mathrm{RE}_{U}$ & $\begin{array}{l}\mathrm{RMA} \\
\text { slope }\end{array}$ & Diff. from 1 & $\begin{array}{l}\text { Species } \\
\text { rank }\end{array}$ \\
\hline \multicolumn{2}{l}{ (A) Monoculture } & & & & & \\
C-N- & 0.93 & 0.22 & 0.57 & 1.17 & No & $p<0.01$ \\
$\mathrm{C}+\mathrm{N}-$ & 0.90 & 0.18 & 0.10 & 1.00 & No & $p<0.05$ \\
$\mathrm{C}+\mathrm{N}+$ & 0.84 & 0.20 & 0.87 & 1.35 & No & $p<0.05$ \\
C-N+ & 0.96 & 0.16 & 1.55 & 0.98 & Yes & $p<0.001$ \\
Species mean & 0.96 & 0.13 & 0.44 & 1.16 & No & $p<0.01$ \\
Overall & 0.94 & 0.19 & 0.10 & 1.01 & No & $p<0.05$ \\
(B) Mixture & & & & & & \\
C+N- & 0.96 & 0.37 & 0.34 & 1.14 & No & $p<0.01$ \\
C+N+ & 0.94 & 0.48 & 0.17 & 1.07 & No & $p<0.01$ \\
C-N- & 0.92 & 0.58 & 0.48 & 1.21 & No & $p<0.05$ \\
C-N+ & 0.92 & 0.50 & 0.40 & 1.18 & No & $p<0.001$ \\
Species mean & 0.96 & 0.37 & 0.83 & 1.15 & No & $p<0.01$ \\
Overall & 0.93 & 0.51 & 0.33 & 1.15 & No & $p<0.05$ \\
\hline
\end{tabular}

with the software - Statgraphics Plus (Manugistics, Rockville, MD, USA).

\section{Results}

In the $\mathrm{C}-\mathrm{N}+$ treatment of monocultures, four parameters (i.e. two from root morphology, OrL and $T r$, and two from axis demography, Tsen $_{0}$ and Intcl) had to be optimized from measured annual above-ground DM yield (DMY) and tiller density, respectively. Moreover, most values of species specific parameter were derived from plant trait measurements in this field treatment (Table 1). Therefore, the good agreement $(d=0.96, \mathrm{RE}=0.16$, Table $3 \mathrm{~A}$ ) between simulated and measured DMY means in the $\mathrm{C}-\mathrm{N}+$ treatment merely indicates that the optimization procedure was successful but cannot be used to assess the model accuracy.

The three other management treatments were then simulated by Gemini using exactly the same set of parameter values and modifying only the cutting frequency and $\mathrm{N}$ supply factors. Despite a lower agreement between observations and simulations for $d$ and $\mathrm{RE}$ in the $\mathrm{C}+\mathrm{N}+$ and $\mathrm{C}-\mathrm{N}-$ treatments respectively (indicating a higher variability of model error and a higher quadratic error, respectively), simulated and measured annual DMY of the three independent treatments were overall in good agreement $(d \geq 0.9$, except for $\mathrm{C}+\mathrm{N}+$ treatment; $\mathrm{RE} \leq 0.2$ except for the $\mathrm{C}-\mathrm{N}-$ treatments) with no systematic bias $\left(R E_{S} / R E_{U}<1\right)$ and no under-or-over estimation (RMA slope never different from 1) (Fig. 3A, Table 3A). Moreover, plant species ranks were significantly correlated for simulated and measured DM yields of the grass monocultures (Fig. 3A, insert and Table 3A).

Within species mixtures, simulated and measured species abundances agreed $(d \geq 0.9)$ and their ranks were significantly correlated. In addition, there was neither a systematic bias $\left(R E_{S} / R E_{U}<1\right)$ nor an under-or-over estimation (RMA slope not significantly different from 1) (Fig. 3B, Table 3B). However, a low overall RE value (0.51) indicated a few large quadratic errors between simulated and measured abundances $(R E>0.2)$. While the relative abundances of dominant (Fig. 3B, insert; $D$. glomerata, $F$. arundinacea, $H$. lanatus were above $20 \%$ ) and subordinate (A. elatius, $P$. pratensis, $A$. pratensis were above $10 \%$ ) species were correctly simulated, the model showed a tendency to over-estimate the relative abundance of rare (relative abundance below 10\%) species.

\section{Discussion}

By combining an individual centered approach coordinating $\mathrm{C}$ and $\mathrm{N}$ metabolisms, shoot and root morphogenesis and tiller demography, we have developed a mechanistic model capable to link plant functional traits, plant populations and community dynamics, and ecosystem fluxes (e.g. net primary productivity). Despite its apparent complexity, the Gemini model is mostly based on sets of widely published and well established mechanistic equations which are derived from first order principles. Moreover, the model brings a high degree of realism, through an explicit dynamic description of plant form and function, and most, if not all, output variables can be compared with ecophysiological, ecological and agronomical measurements both in the field and in controlled environment studies.

While the model requires a large number of parameters for each plant population, we have shown that it can be readily parameterized from root and shoot trait values measured in field experiments. The development of international trait databases (e.g. TRY, Kattge et al., 2011) will expand the list of traits and of species that can be used for model parameterization.

After parameterization under optimal environmental conditions, the model was able to simulate accurately both inter and intra-specific variation in response to nitrogen and disturbance of pasture grass dry-matter yields (Table $3 \mathrm{~A}$, Fig. $3 \mathrm{~A}$ ). Indeed, for the three independent management treatments $(\mathrm{C}-\mathrm{N}-, \mathrm{C}+\mathrm{N}-, \mathrm{C}+\mathrm{N}+)$ which were not used for model parameterization: (i) simulated and observed species ranks for DM yields in monocultures were significantly correlated without bias and (ii) acceptable model errors were shown by two statistical indices ( $d$ and RE).

The dual description (morphology and metabolism) of plant populations provided by the model is unified considering a minimum law. Both ontogeny (morphogenetic processes) and functional balance (physiological processes) may limit the actual growth rate of roots and shoots. Plant populations are therefore driven through a dually constrained manifold that keeps their form and function within plastic limits. Supply limitation occurs whenever assimilates supply is less than assimilates demand. Demand limitation occurs whenever assimilate demand is less than assimilate supply, leading to excess assimilates being allocated to the $C$ and $\mathrm{N}$ substrate pools.

Resorption during leaf and root senescence leads to $\mathrm{C}$ and $\mathrm{N}$ fluxes towards the substrate pools. Therefore, part of the assimilate supply for tissue growth depends upon tissue senescence. In the same way, axis death provides through resorption additional substrates, which may be used for vegetative multiplication, that is the emission and outgrowth of new axes. Thus, ontogeny not only requires, but also provides assimilates.

In a dynamic loop, morphogenesis leads to changes in the length and area of root and shoot captors, which affect resource capture and availability and hence assimilate supply for morphogenesis. At the population level, vegetative multiplication of axes leads to lower resource availability for each individual axis, to lower substrate levels and, hence, to increasing limitations on the formation of new axes.

Vegetative multiplication implies a transition from heterotrophy to autotrophy of the newly formed axes. Autotrophy is assumed at the stage when the net carbon balance of a newly formed axis (i.e. photosynthesis minus maintenance respiration) becomes positive, as a result of leaf extension into unshaded canopy layers. Thus, autotrophy is gained earlier in open compared to dense stands. On average, autotrophy accounts for two thirds (data not shown) of the 

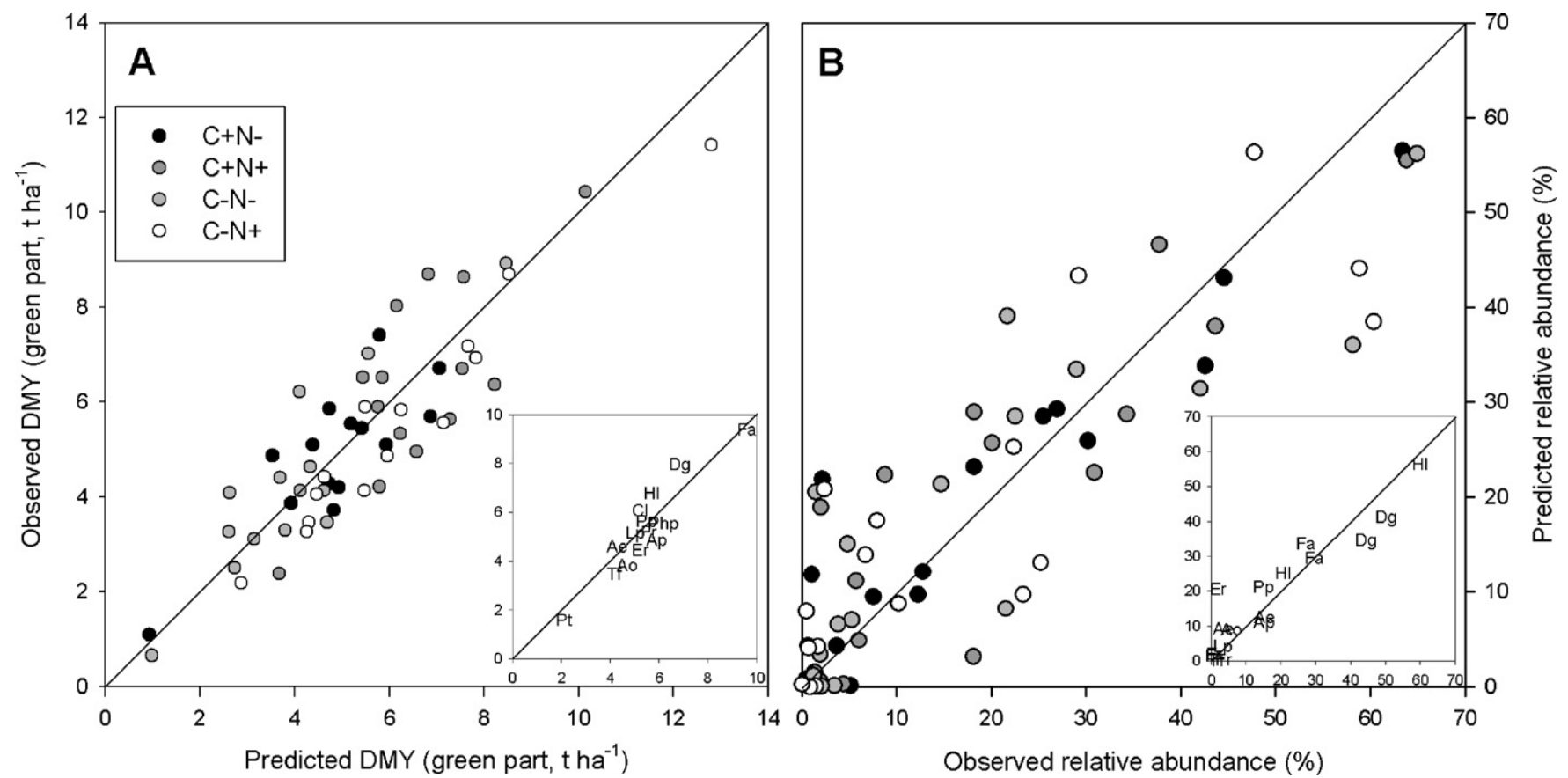

Fig. 3. (A) Simulated versus measured above-ground vegetative dry matter yields (DMY) of 13 grass species and of a Lolium cultivar grown in monocultures with four management treatments ( $\mathrm{C}-, \mathrm{C}+: 3$ and 6 cuts per year; $\mathrm{N}-, \mathrm{N}+: 120$ and $360 \mathrm{kgN} \mathrm{ha}^{-1} \mathrm{yr}^{-1} \mathrm{~N}$ fertilizer supply). Model was calibrated and optimized with data from the $\mathrm{C}-\mathrm{N}+$ treatment only. A restart procedure after spin-up runs was used to initialize simulations. (B) Simulated versus measured relative abundance of grass species grown in mixtures with four management treatments. Three mixtures of six species each were drawn at random from a pool of $12 \mathrm{species:} \mathrm{(i)} D g$, Fa, Fr, $L p, P p$, C. cristatus; (ii) Ap, Ao, $A e, E r, H l, T f$; (iii) Ae, Dg, Er, Fa, Fr, Hl. The simulations started with a total initial mixture density of 1000 axes $\mathrm{m}^{-2}$, with each species having the same initial axis density. See Table 2 for species abbreviations.

total $\mathrm{C}$ required for the construction of a new tiller that has reached maturity (i.e. two leaves at least).

Predicting directional changes in grassland community structure in response to environmental factors has proved to be difficult (Suding et al., 2003). Gemini simulated adequately the plant community structure within mixtures of six species (Table 3B, Fig. 3B), thereby capturing directional changes in community structure in response to nutrients ( $\mathrm{N}$ supply) and disturbance (cutting frequency) drivers. Despite this overall agreement, relatively high quadratic errors were found in some instances, indicating that there is scope for further improvements of the model. Given the trade-off reported for the same grass species (Maire et al., 2009) between nitrate and ammonium root uptake capacities, simulating the uptake and soil dynamics of these two mineral $\mathrm{N}$ forms could help refining the model and reducing prediction errors of grass species relative abundance (a significant relationship was found between the residuals of the observed/predicted abundance curve and the root uptake capacities of these species, data not shown).

We do not know of another mechanistic grassland model that can predict nitrogen and disturbance effects on relative abundance in mixtures including more than three species (but for three species mixtures, see Van Wijk, 2007). In recent years there have been attempts to predict changes in vegetation structure caused by global change, with dynamic global vegetation models (DGVMs, Cramer et al., 2001). These models consider several plant functional types (such as evergreen and deciduous trees, $C_{3}$ and $C_{4}$ grasses) that co-occur within a given grid box, and some models (Hybrid, Friend et al., 1997; LPJ, Sitch et al., 2003; Orchidee, Krinner et al., 2005) simulate competition between these types. The Gemini model uses plant traits rather than plant functional types to simulate both directional changes in species composition and their effects on ecosystem functioning. This approach could be extended within the framework of future DGVMs (Van Wijk, 2007).

\section{Conclusion}

The Gemini model provides for the first time a trait-based mechanistic framework for modeling the role of grass diversity and plasticity on community dynamics and ecosystem functioning. The aim of this paper was to first present the model and evaluate its behavior. The first results presented here show that the model can predict productivity patterns both within and across species, and simulate the main directional changes in plant community structure in response to environmental factors. In a second paper (Maire et al., in press), emergent properties of the model (e.g. critical $\mathrm{N}$ content and self-thinning laws) and the needs for keeping this degree of model complexity have been tested. Further applications of the model are currently being developed including in silico experiments on the biodiversity-ecosystem functioning relationships and plant trait space analyses (Gross et al., in press). Further work will also be needed to extend the model to other plant functional types such as forbs and fully account for the effects of water deficit. This will open the possibility to model mechanistically multi-species grassland systems and help to understand the mechanistic links between individual, community and ecosystem responses to global changes.

\section{Acknowledgements}

This study was financially supported by the French ANR DISCOVER (ANR-05-BDIV-010-01) and ANR QDIV (ANR-05-BDIV009-01) projects and by the FEDER, 'l'Europe s'engage en région Auvergne'. V. Maire was funded by a Ph-D grant of French Research Ministry. We thank C. Picon-Cochard for constructive comments on root parameterization, Hoglah Dasari and two anonymous referees who provided helpful comments on previous versions of the manuscript. 


\section{References}

Allen, M.T., Prusinkiewicz, P., DeJong, T.M., 2005. Using L-systems for modeling source-sink interactions, architecture and physiology of growing trees: the LPEACH model. New Phytol. 166, 869-880.

Barber, S.A., 1995. Soil Nutrient Bioavailability. A Mechanistic Approach, 2nd ed John Wiley \& Sons, Inc, New York, USA, 414 pp.

Bouman, B.A.M., Schapendonk, A.H.C.M., Stol, W., Van Kraalingen, D.W.G., 1996 Description of the growth model LINGRA as implemented in CGMS. Quant. Appro. Syst. Anal. 7, 1-56.

Brouwer, R., 1962. Nutritive influences on the distribution of dry matter in the plant. Netherlands J. Agric. Sci. 10, 399-408.

Cellier, F.E., Kofman, E., 2005. Continuous System Simulation. Springer-Verlag, New York, USA, 617 pp.

Chapin III, F.S., 1991. Integrated responses of plants to stress. A centralized system of physiological responses. Bioscience 41, 29-36.

Chen, J.L., Reynolds, J.F., Harley, P.C., Tenhunen, J.D., 1993. Coordination theory of leaf nitrogen distribution in a canopy. Oecologia 93, 63-69.

Cornelissen, J.H.C., Lavorel, S., Garnier, E., Diaz, S., Buchmann, N., et al., 2003. A handbook of protocols for standardised and easy measurement of plant functional traits worldwide. Aust. J. Bot. 51 (4), 335-380.

Craine, J.M., Tilman, D., Wedin, D., Reich, P., Tjoelker, M., Knops, J., 2002. Functional traits, productivity and effects on nitrogen cycling of 33 grassland species. Funct. Ecol. 16, 563-574.

Cramer, W., Bondeau, A., Woodward, F.I., Prentice, I.C., Betts, R.A., Brovkin, V., Cox, P.M., Fisher, V., Foley, J.A., Friend, A.D., Kucharik, C., Lomas, M.R., Ramankutty, N., Sitch, S., Smith, B., White, A., Young-Molling, C., 2001. Global response of terrestrial ecosystem structure and function to $\mathrm{CO}_{2}$ and climate change: results from six dynamic global vegetation models. Global Change Biol. 7 357-373.

Davies, A., 1974. Leaf tissue remaining after cutting and regrowth in perennial ryegrass. J. Agric. Sci. 82, 165-172.

Davidson, R.L., 1969. Effect of root/leaf temperature differentials on root/shoot ratios in some pasture grasses and clover. Ann. Bot. 33, 561-569.

Enquist, B.J., Niklas, K.J., 2002. Global allocation rules for patterns of biomass partitioning in seed plants. Science 295, 1517-1520.

Farquhar, G.D., Von Caemmerer, S., Berry, J.A., 1980. A biochemical model of photosynthetic $\mathrm{CO}_{2}$ assimilation in leaves of $C_{3}$ species. Planta $149,78-90$.

Field, C., 1983. Allocating leaf nitrogen for the maximization of carbon gain: leaf age as a control on the allocation program. Oecologia 56, 341-347.

Field, C.B., Chapin, F.S., Matson, P.A., Mooney, H.A., 1992. Responses of terrestrial ecosystems to the changing atmosphere: a resource-based approach. Ann. Rev. Ecol. Evol. Syst. 23, 201-235.

Franklin, O., Agren, G.I., 2002. Leaf senescence and resorption as mechanisms of maximizing photosynthetic production during canopy development at $\mathrm{N}$ limitation Funct. Ecol. 16, 727-733.

Friend, A.D., Stevens, A.K., Knox, R.G., Cannell, M.G.R., 1997. A process-based, terrestrial biosphere model of ecosystem dynamics (Hybrid v3.0). Ecol. Model. 95 249-287.

Gillet, M., 1980. Les graminées fourragères. Description, fonctionnement. In: application à la culture de l'herbe. INRA Publisher, Versailles, France, 230 pp.

Grimm, V., Berger, U., Bastiansen, F., Eliassen, S., Ginot, V., Giske, J., Goss-Custard, J., Grand, T., Heinz, S.K., Huse, G., Huth, A., Jepsen, J.U., Jorgensen, C., Mooij, W.M. Muller, B., Pe'er, G., Piou, C., Railsback, S.F., Robbins, A.M., Robbins, M.M., Rossmanith, E., Ruger, N., Strand, E., Souissi, S., Stillman, R.A., Vabo, R., Visser, U., DeAngelis, D.L., 2006. A standard protocol for describing individual-based and agent-based models. Ecol. Model. 198, 115-126.

Groot, J.C.J., Lantinga, E.A., 2004. An object-oriented model of the morphological development and digestibility of perennial ryegrass. Ecol. Model. 177, 297-312.

Gross, N., Kunstler, G., Liancourt, P., Bello, F., Suding, K.N., Lavorel, S., 2009. Linking individual response to biotic interactions with community structure: a traitbased framework. Funct. Ecol. 23, 1167-1178.

Gross, N., Maire, V., Wirth, C., Hill, D., Soussana, J.F. Disentangling coordination among functional traits using an individual-based model: Impact on plant performance and trait variability. PlosOne, in press.

Gross, N., Suding, K.N., Lavorel, S., 2007a. Leaf dry matter content and lateral spread predict response to land use change for six subalpine grassland species. J. Veget. Sci. 18, 289-300.

Gross, N., Suding, K.N., Lavorel, S., Roumet, C., 2007b. Complementarity as a mechanism of coexistence between functional groups of grasses. J. Ecol. 95, 1296-1305.

Hilbert, D.W., Reynolds, J.F., 1991. A model allocating growth among leaf proteins, shoot structure, and root biomass to produce balanced activity. Ann. Bot. 68, $417-425$.

Hirose, T., Werger, M.J.A., 1987. Maximizing daily canopy photosynthesis with respect to the leaf nitrogen allocation pattern in the canopy. Oecologia 72 $520-526$.

Hoglind, M., Schapendonk, A., Van Oijen, M., 2001. Timothy growth in Scandinavia: combining quantitative information and simulation modelling. New Phytol. 151 355-367.

Imsande, J., Touraine, B., 1994. N demand and the regulation of nitrate uptake. Plant Physiol. 105, 3-7.

Jeuffroy, M.H., Ney, B., Ourry, A., 2002. Integrated physiological and agronomic modelling of $\mathrm{N}$ capture and use within the plant. J. Exp. Bot. 53, 809-823.

Johnson, I.R., Thornley, J.H.M., 1987. A model of shoot:root partitioning with optimal growth. Ann. Bot. 60, 133-142.
Kattge, J., Díaz, S., Lavorel, S., Prentice, I.C., Leadley, P., Bönisch, G., Garnier, E., Westoby, M., Reich, P.B., Wright, I.J., et al., 2011. TRY - a global database of plant traits. Global Change Biol., doi:10.1111/j.1365-2486.2011.02451.x.

Kazakou, E., Garnier, E., Navas, M.L., Roumet, C., Collin, C., Laurent, G., 2007. Components of nutrient residence time and the leaf economics spectrum in species from Mediterranean old-fields differing in successional status. Funct. Ecol. 21, 235-245.

Klumpp, K., Soussana, J.-F., 2009. Using functional traits to predict grassland ecosystem change: a mathematical test of the response-and-effect trait approach. Global Change Biol. 15, 2921-2934.

Krinner, G., Viovy, N., de Noblet-Ducoudré, N., Ogée, J., Polcher, J., Friedlingstein P., Ciais, P., Sitch, S., Prentice, I.C., 2005. A dynamic global vegetation mode for studies of the coupled atmosphere-biosphere system. Global Biogeochem. Cycles 19, GB1015.

Kutschera, L., 1960. Wurzelatlas mitteleuropäischer ackerunkräuter und kulturpflanzen. DLG Verlag, Frankfurt am Main, Germany, 574 pp.

Lafarge, M., Mazel, C., Hill, D.R.C., 2005. A modelling of the tillering capable of reproducing the fine-scale horizontal heterogeneity of a pure grass sward and its dynamics. Ecol. Model. 183, 125-141.

Lavorel, S., Diaz, S., Cornelissen, J.H.C., Garnier, E., Harrison, S.P., McIntyre, S., Pausas, J.G., Pérez-Harguindeguy, N., Roumet, C., Urcelay, C., 2007. Plant functional types: are we getting any closer to the Holy Grail? In: Canadell, J., Pitelka, L.F., Pataki, D. (Eds.), Terrestrial Ecosystems in a Changing World. IGBP Book. Springer-Verlag, pp. 149-159.

Lavorel, S., McIntyre, S., Landsberg, J., Forbes, T.D.A., 1997. Plant functional classifications: from general groups to specific groups based on response to disturbance. Trends Ecol. Evol. 12, 474-478.

Lazzarotto, P., Calanca, P., Fuhrer, J., 2009. Dynamics of grass-clover mixtures: an analysis of the response to management with the productive grassland simulator (Prograss). Ecol. Model. 220, 703-724.

Lehsten, V., Kleyer, M., 2007. Turnover of plant trait hierarchies in simulated community assembly in response to fertility and disturbance. Ecol. Model. 203, $270-278$.

Lemaire, G., 1999. Les flux de tissus foliaires au sein des peuplements prairiaux. Eléments pour une conduite raisonnée du pâturage. Fourrages 159, 203-222.

Lemaire, G., Agnusdei, M., 2000. Leaf tissue turnover and efficiency of herbage utilization. In: Grassland Ecophysiology and Grazing Ecology. CABI Publishing Wallingford, UK, pp. 265-287.

Le Roux, X., Lacointe, A., EscobarGutierrez, A., LeDizes, S., 2001. Carbon-based models of individual tree growth: a critical appraisal. Ann. Forest Sci. 58, 469-506.

Loreau, M., Naeem, S., Inchausti, P., 2002. Perspectives and challenges. In: Loreau, M., Naeem, S., Inchausti, P. (Eds.), Biodiversity and Ecosystem Functioning: Synthesis and Perspectives. Oxford University Press, Oxford, UK pp. 237-242.

Lötscher, M., Stroh, K., Schnyder, H., 2003. Vertical leaf nitrogen distribution in relation to nitrogen status in grassland plants. Ann. Bot. 92, 679-688.

Louault, F., Pillar, V.D., Aufrere, J., Garnier, E., Soussana, J.-F., 2005. Plant traits and functional types in response to reduced disturbance in a semi-natural grassland. J. Veget. Sci. 16, 151-160.

Maire, V., Gross, N., Pontes, L., Picon-Cochard, C., Soussana, J.-F., 2009. Trade-off between root nitrogen acquisition and shoot nitrogen utilization across 13 cooccurring pasture grass species. Funct. Ecol. 23, 668-679.

Maire, V., Soussana, J.F., Gross, N., Bachelet, B., Martin, R., Pages, L., Reinhold, T., Wirth, C., Hill, D., in press. Gemini: a grassland model simulating the role of plant traits for community dynamics and ecosystem functioning. Part II: Emergent properties and role of plant plasticity. Ecol. Model.

Maire, V., 2009. From functional traits of grasses to the functioning of grassland ecosystem: A. Mechanistic modelling approach. Ph.D. Thesis. Blaise Pascal University, Clermont-Ferrand, France, $300 \mathrm{pp}$.

Marks, C.O., Lechowicz, M.J., 2006. A holistic tree seedling model for the investigation of functional trait diversity. Ecol. Model. 193, 141-181.

Matthew, C., Yang, J.Z., Potter, J.F., 1998. Determination of tiller and root appearance in perennial ryegrass (Lolium perenne) swards by observation of the tiller axis, and potential application in mechanistic modelling. New Zeal. J. Agric. Res. 41 1-10.

McGill, B.J., Enquist, B.J., Weiher, E., Westoby, M., 2006. Rebuilding community ecology from functional traits. Trends Ecol. Evol. 21, 178-185.

Millard, P., 1988. The accumulation and storage of nitrogen by herbaceous plants. Plant Cell Environ. 11, 1-8.

Neuteboom, J.H., Lantinga, E.A., 1989. Tillering potential and relationship between leaf and tiller production in perennial Ryegrass. Ann. Bot. 63, 265-270.

Nijs, I., Behaeghe, T., Impens, I., 1995. Leaf nitrogen content as a predictor of photosynthetic capacity in ambient and global change conditions. J. Biogeogr. 22 , $177-183$.

Norberg, J., Swaney, D.P., Dushoff, J., Lin, J., Casagrandi, R., Levin, S.A., 2001. Phenotypic diversity and ecosystem functioning in changing environments: a theoretical framework. Proc. Natl. Acad. Sci. U.S.A. 98, 11376-11381.

Pagès, L., Vercambre, G., Drouet, J.-L., Lecompte, F., Collet, C., Le Bot, J., 2004. Root Typ: a generic model to depict and analyse the root system architecture. Plan Soil 258, 103-119.

Pontes, L.D.S., Soussana, J.-F., Louault, F., Andueza, D., Carrere, P., 2007. Leaf traits affect the above-ground productivity and quality of pasture grasses. Funct. Ecol. $21,844-853$.

Pontes, L.D., Louault, F., Carrere, P., Maire, V., Andueza, D., Soussana, J.F., 2010. The role of plant traits and their plasticity in the response of pasture grasses to nutrients and cutting frequency. Ann. Bot. 105, 957-965. 
Pontes, L., da, S., Maire, V., Louault, F., Soussana, J.-F., Carrère, P., 2012. Impacts of species interactions on grass community productivity under contrasting management regimes. Oecologia 168 (3), 761-771.

Poorter, H., 1994. Construction costs and payback time of biomass: a whole plant perspective. In: Roy, J., Garnier, E. (Eds.), A Whole Plant Perspective on CN Interactions. Acc. Publ., The Hague, pp. 11-127.

Savage, V.M., Webb, C.T., Norberg, J., 2007. A general multi-trait-based framework for studying the effects of biodiversity on ecosystem functioning. J. Theor. Biol. 247, 213-229.

Schippers, P., Kropff, M.J., 2001. Competition for light and nitrogen among grassland species: a simulation analysis. Funct. Ecol. 15, 155-164.

Schymanski, S., 2008. Optimality as a concept to understand and model vegetation at different scales. Geogr. Compass 2 (5), 1580-1598.

Sheehy, J.E., Gastal, F., Mitchell, P.L., Durand, J.L., Lemaire, G., Woodward, F.I., 1996. A nitrogen-led model of grass growth. Ann. Bot. 77, 165-177.

Simon, J.C., Lemaire, G., 1987. Tillering and leaf area index in grasses in vegetative phase. Grass Forage Sci. 42, 373-380.

Sinoquet, H., Rakocevic, M., Varlet-Grancher, C., 2000. Comparison of models for daily light partitioning in multispecies canopies. Agric. Forest Meteorol. 101, 251-263.

Sitch, S., Smith, B., Prentice, I.C., Arneth, A., Bondeau, A., Cramer, W., Kaplan, J.O., Levis, S., Lucht, W., Sykes, M.T., Thonicke, K., Venevsky, S., 2003. Evaluation of ecosystem dynamics, plant geography and terrestrial carbon cycling in the LPJ dynamic global vegetation model. Global Change Biol. 9, 161-185.

Soussana, J.-F., Lafarge, M., 1998. Competition for resources between neighbouring species and patch scale vegetation dynamics in temperate grasslands. Ann. Zootechn. 47, 371-382.

Soussana, J.-F., Teyssonneyre, F., Thiery, J.M., 2000a. Un modèle dynamique d'allocation basée sur l'hypothèse d'une co-limitation de la croissance végétale par les absorptions de lumière et d'azote. In: Bonhomme, M.P. (Ed.), Fonctionnement des peuplements végétaux et environnement. INRA Editions, Paris, pp. 87-116.

Soussana, J.-F., Teyssonneyre, F., Thiery, J.M., 2000b. Un modèle simulant les compétitions pour la lumière et pour l'azote entre espèces herbacées à croissance clonale. In: Bonhomme, M.P. (Ed.), Fonctionnement des peuplements végétaux sous contraintes environnementales. INRA Editions, Paris, pp. $117-145$.

Soussana, J.-F., Minchin, F.R., Macduff, J.H., Raistrick, N., Abberton, M.T., MichaelsonYeates, T.P.T., 2002. A simple model of feedback regulation for nitrate uptake and $\mathrm{N}_{2}$ fixation in contrasting phenotypes of white clover. Ann. Bot. 90, 425.

Stöckle, C.O., Kjelgaard, J., Belocchi, G., 2004. Evaluation of estimated weather data for calculating Penman-Monteith reference crop evapotranspiration. Irrig. Sci. $23,39-46$.

Suding, K.N., Goldberg, D.E., Hartman, K.M., 2003. Relationships among species traits: separating levels of response and identifying linkages to abundance. Ecology $84,1-16$.
Suding, K.N., Lavorel, S., Chapin, F.S., Cornelissen, J.H.C., Diaz, S., Garnier, E., Goldberg, D., Hooper, D.U., Jackson, S.T., Navas, M.L., 2008. Scaling environmental change through the community-level: a trait-based response-and-effect framework for plants. Global Change Biol. 14, 1125-1140.

Tilman, D., 1988. Plant Strategies and the Dynamics and Structure of Plant Communities. Princeton University Press, Princeton, USA, 360 pp.

Tilman, D., 1990. Constraints and tradeoffs: toward a predictive theory of competition and succession. Oikos 58 (1), 3-15.

Thornley, J.H.M., Johnson, I.R., 1990. Plant and Crop Modelling: A Mathematical Approach to Plant and Crop Physiology. Oxford University Press, Oxford, UK, $\mathrm{xv}+669 \mathrm{pp}$.

Tomlinson, K.W., Dominy, J.G., Hearne, J.W., O'Connor, T.G., 2007. A functional-structural model for growth of clonal bunchgrasses. Ecol. Model. 202, 243-264.

Van Loo, E.N., 1992. Tillering, leaf expansion and growth of plants of two cultivars of perennial ryegrass grown using hydroponics at two water potentials. Ann. Bot. 70, 511-518.

Van Oijen, M., Hoglind, M., Hanslin, H.M., Caldwell, N., 2005. Process based modelling of timothy regrowth. American Society of Agronomy 97, 1-9.

Van Wijk, M.T., 2007. Predicting ecosystem functioning from plant traits: results from a multi-scale ecophysiological modelling approach. Ecol. Model. 203, 453-463.

Villeger, S., Mason, N.W.H., Mouillot, D., 2008. New multidimensional functional diversity indices for a multifaceted framework in functional ecology. Ecology $89,2290-2301$.

Violle, C., Navas, M.L., Vile, D., Kazakou, E., Fortunel, C., Hummel, I., Garnier, E., 2007. Let the concept of trait be functional! Oikos 116, 882-892.

West, G.B., Brown, J.H., Enquist, B.J., 1999. A general model for the structure and allometry of plant vascular systems. Nature 400, 664-667.

Willmott, C.J., 1982. Some comments on the evaluation of model performance. Bull. Am. Meteor. Soc. 63, 1309-1313.

Wilson, J.B., 1988. A review of evidence on the control of shoot:root ratio, in relation to models. Ann. Bot. 61, 433-449.

Wohlfahrt, G., Bahn, M., Horak, I., Tappeiner, U., Cernusca, A., 1998. A nitrogen sensitive model of leaf $\mathrm{CO}_{2}$ and $\mathrm{H}_{2} \mathrm{O}$ vapour gas exchange: application to $13 \mathrm{key}$ species from differently managed mountain grassland ecosystems. Ecol. Model. 113, 179-199.

Wohlfahrt, G., Bahn, M., Haubner, E., Horak, I., Michaeler, W., Rottmar, K., Tappeiner, U., Cernusca, A., 1999. Inter-specific variation of the biochemical limitation to photosynthesis and related leaf traits of 30 species from mountain grassland ecosystems under different land use. Plant Cell Environ. 22, 1281-1296.

Wohlfahrt, G., Bahn, M., Tappeiner, U., Cernusca, A., 2000. A model of whole plant gas exchange for herbaceous species from mountain grassland sites differing in land use. Ecol. Model. 125, 173-201.

Yin, X., Schapendonk, A., 2004. Simulating the partitioning of biomass and nitrogen between roots and shoot in crop and grass plants. Njas-Wageningen J. Life Sci. 51, 407-426. 